\title{
Porphyroblast microstructures: A review of current and future trends
}

\author{
S.E. JOHNSON* \\ Department of Earth and Planetary Sciences, Macquarie University, Sydney, New South Wales 2109, Australia
}

\begin{abstract}
Many recent papers show how porphyroblast microstructures play an important role in a wide range of structural and metamorphic studies. This paper reviews ten current applications of these microstructures: (1) porphyroblast growth-timing criteria; (2) tracking progressive foliation development relative to changing metamorphic conditions; (3) timing of pluton emplacement relative to deformation and metamorphism; (4) finite longitudinal strain determinations; (5) kinematics and porphyroblast rotation; (6) use of linear fabrics preserved in porphyroblasts; (7) porphyroblasts and folding mechanisms; (8) inclusion-trail orientations and orogenic processes; (9) inferring shear-strain rates from porphyroblast growth rates; and (10) in-situ age determinations. Although there is still no concensus on the interpretation of some porphyroblast microstructures, a bright future lies ahead as traditional and newly developed techniques of microstructural analysis are combined with modern chemical and microprobe techniques to provide an increased understanding of the relationships between deformation and metamorphism in a wide range of metamorphic settings.
\end{abstract}

\section{INTRODUCTION}

This paper reviews some current applications of porphyroblast microstructures, some difficulties with interpreting them, and some possible directions for future studies. Porphyroblast microstructures have attracted the attention and imagination of geologists for more than a century, and have enjoyed a resurgence in popularity over the last two decades. Although commonly complex, they are of broad interest as a tool for evaluating deformation and metamorphic processes, and for unravelling histories of deformed metamorphic rocks. Apart from their research value, porphyroblasts are useful teaching devices because they are relatively easy to observe and describe. The question of how most porphyroblast microstructures develop is linked to fundamental questions and controversies concerning structural and metamorphic processes. Thus, porphyroblasts can be used as learning models for processes, at various scales, that may be difficult to visualize. The issue of how to interpret these microstructures has strongly polarized structural geologists over the last two decades, and an example of how controversial the topic has become is illustrated by the full-length discussion and reply papers of Passchier et al. (1992) and Bell et al. (1992). Regardless of the controversy, renewed popularity has led to the refinement of some classical techniques of microstructural analysis, and the development of several new ones.

*Address after January 1, 2000: Department of Geological Sciences, University of Maine, Orono, Maine 04469-5790, U.S.A.

\section{APPLICATIONS OF PORPHYROBLAST MICROSTRUCTURES}

\section{Porphyroblast growth-timing criteria}

The timing of porphyroblast growth relative to the development of surrounding foliations is a fundamental requirement for most applications of porphyroblast microstructures: are the porphyroblasts pre-, syn-, or post-kinematic? Such relative timing allows the growth of different porphyroblastic minerals to be ordered chronologically, leading to inferrence of a time sequence of metamorphic assemblages. This information is very useful for understanding pressure-temperature-deformationtime $(P-T-D-t)$ paths experienced by metamorphic rocks, and thus for inferring the temporal and spatial relationships between deformation and metamorphism-a topic discussed in the next section.

Zwart $(1960,1962)$ attempted to categorize relative timing relationships between porphyroblast growth and the development of matrix foliations (Fig. 1). Although this work was seminal in its time, Vernon (1978) emphasized that many of the criteria were ambiguous, and that microstructures must be interpreted carefully to avoid ambiguity and misleading inferences. In a landmark study, Bell and Rubenach (1983) proposed a six-stage model for crenulation-cleavage development (Fig. 2 ), and argued that inclusion-trail geometries in different porphyroblasts reflect the timing of porphyroblast growth relative to the stage of cleavage development. Bell and Rubenach (1983) suggested that many inclusion-trail complexities could be resolved within this framework, and that the ambiguities noted by Vernon (1978) could generally be resolved by examining multiple thin sections cut in different orientations. The 

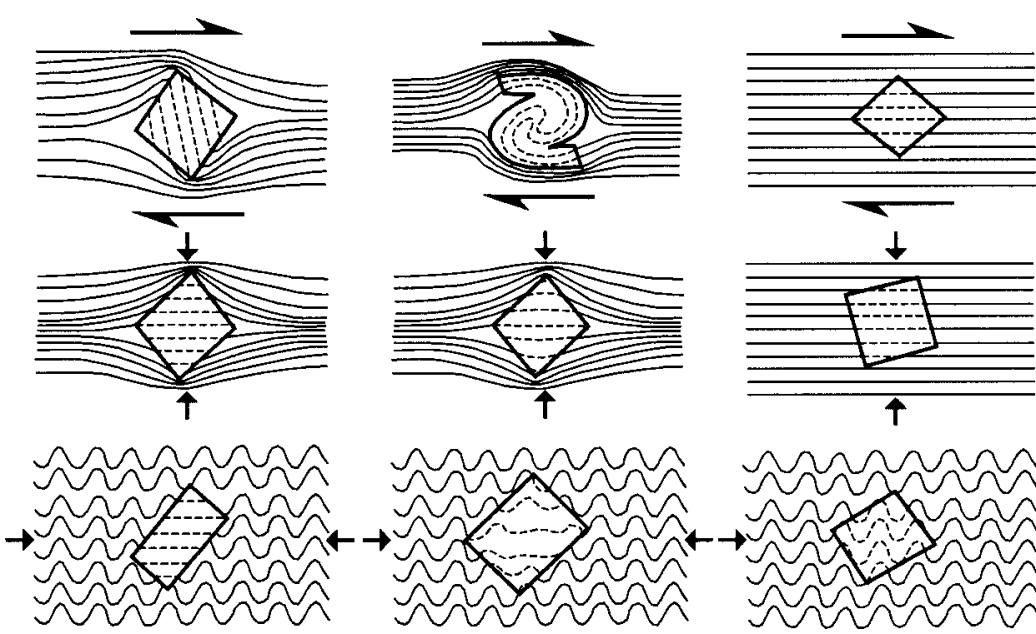

pre-kinematic

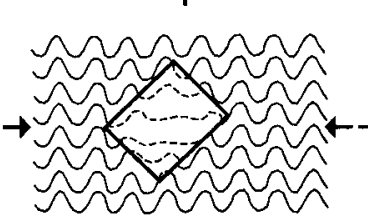

syn-kinematic

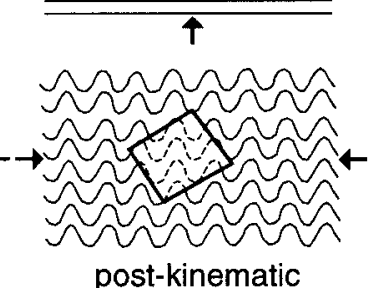

FIGURE 1. Diagram showing pre-, syn- and post-tectonic timing of porphyroblast growth relative to matrix foliation development, depending on the type of strain (indicated by arrows). After Zwart (1962).
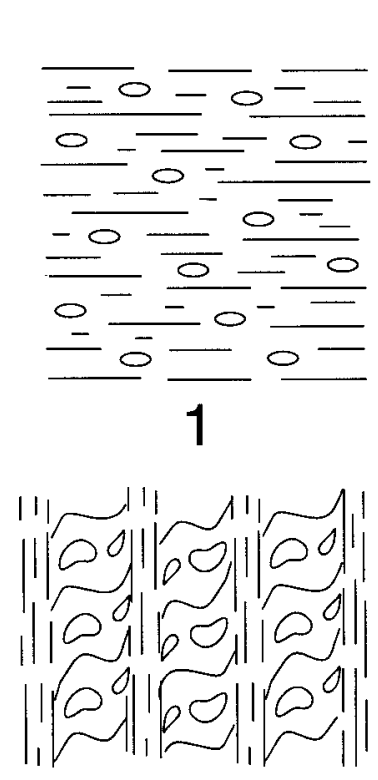

4
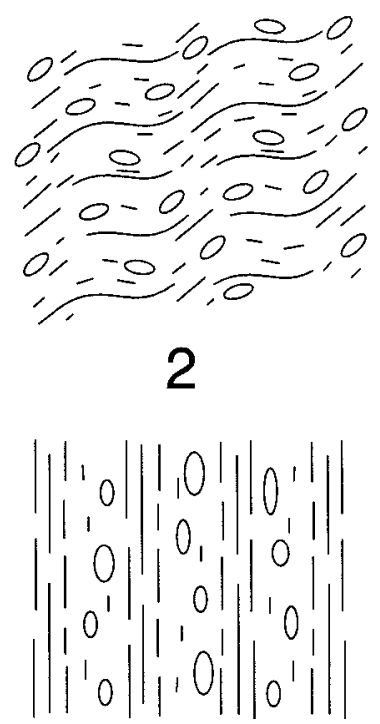

5
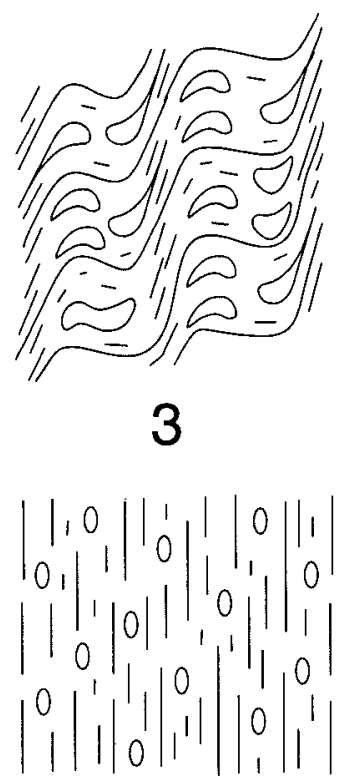

FiguRE 2. Six stages of crenulationcleavage development to form a new foliation. (1) Original foliation. (2) Development of crenulation. (3) Development of metamorphic differentiation in the crenulation septa (Mdomains). (4) Growth of new mica in the crenulation septa. (5) Destruction of relic crenulations in microlithons (Q-domains). (6) Homogeneous new foliation. After Bell and Rubenach (1983). use of multiple, spatially oriented thin sections has become a progressively more important theme in detailed microstructural studies (e.g., Hayward 1992; Davis 1993; Wilkins 1993; Johnson and Vernon 1995a; Bell and Hickey 1997; Bell et al. 1998; Morgan et al. 1998; Hickey and Bell 1999).

An important implication of Bell and Rubenach (1983) was that syn-kinematic porphyroblasts could potentially be misinterpreted as pre- or post-kinematic if they grew very early or very late during deformation, respectively. Bell et al. (1986) and Bell and Hayward (1991) took this point to its extreme, suggesting that all porphyroblasts probably nucleate and grow during deformation, effectively rejecting the pre- and post-kinematic classifications. Although porphyroblast-matrix microstructural relationships most commonly suggest syn-kinematic growth, Vernon et al. $(1992,1993)$ have documented microstructures that suggest both pre- and post-kinematic growth, at least on the scale of a large thin section. As pointed out by Vernon (1989) and Bell and Hayward (1991), pre-, syn-, or post-kinematic interpretations may depend on the scale of observation relative to the scale of deformation partitioning; but where do we draw the line? If deformation is occurring $100 \mathrm{~m}$ away from a growing porphyroblast, is the porphyroblast still 
syn-kinematic?

Although our understanding has increased considerably over the past two decades, microstructural timing relationships are commonly complex and require consideration of multiple interpretations. Johnson and Vernon (1995a) listed the following as desirable evidence of the relative timing between deformation and metamorphism: (1) sequentially grown porphyroblasts that show clear growth-timing relationships relative to surrounding foliations; (2) partial replacement microstructures, which provide relative timing of metamorphic reactions that cannot be timed relative to foliation development; (3) a tectonic marker foliation that allows correlation of foliations from one location to another; and (4) single samples containing all of the foliations, and all generations of porphyroblast growth, within a single metamorphic zone. Difficult timing relationships can sometimes be resolved by examining porphyroblast strain shadows and the asymmetry of curved inclusion trails (Fig. 3), and

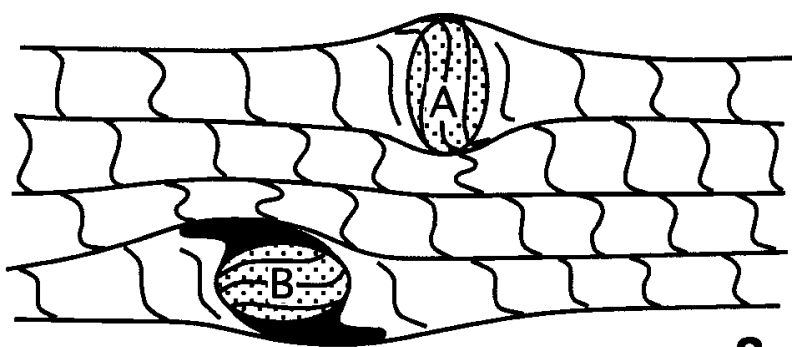

a

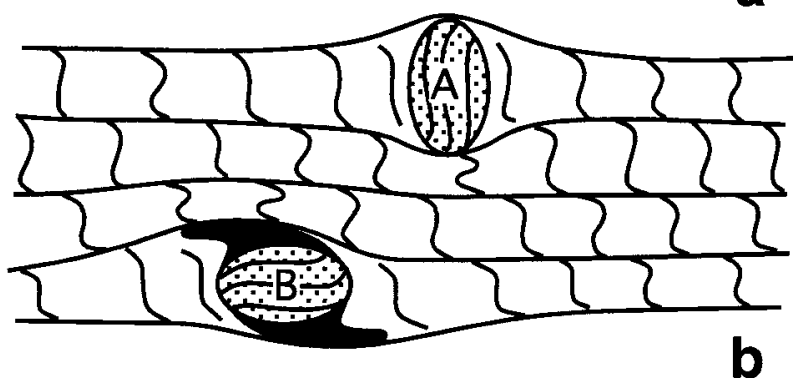

FIGURE 3. Diagrams illustrating the role that deformed strain shadows and inclusion-trail asymmetry can play in determing sequences of porphyroblast growth. (a) Porphyroblast A has inclusion trails with the same asymmetry as crenulations in the matrix, and the inclusion trails are continuous with the matrix foliation. These observations are reliable indicators of growth during crenulation cleavage development. Porphyroblast B has strain shadows that are folded into the overprinting crenulation cleavage, and so it predates both the cleavage and porphyroblast A. If there was no continuity between the inclusion trails and external foliation in porphyroblast $\mathrm{A}$, the reliability of this determination would be diminished. (b) In this instance, the inclusion trails in porphyroblast A have the opposite asymmetry to matrix crenulations, and there is no continuity between the trails and matrix foliation. This evidence indicates that porphyroblast A did not grow during the development of the crenulation cleavage, and there is no reliable evidence on which to suggest whether it postdates, predates or grew synchronously with porphyroblast B. After Johnson and Vernon (1995b). the reliability of all these studies is greatly enhanced if continuity exists between a matrix foliation and the inclusion trails in one or more of the sequential generations of porphyroblast growth (Fig. 3; Johnson and Vernon 1995b).

\section{Tracking progressive foliation development relative to changing metamorphic conditions}

If prograde metamorphic changes occur during the development of a single foliation, sequential or episodic porphyroblast growths may preserve different stages of foliation development (Fig. 4), thus preserving information about the rate of fabric evolution relative to changes in metamorphic conditions. An important framework for this type of study was provided by Bell and Rubenach (1983), who proposed the six-stage model for crenulation-cleavage development introduced in the previous section (Fig. 2). This framework has been used in several papers to understand better the spatial and temporal relationships between deformation and metamorphism (e.g., Bell and Rubenach 1983; Jamieson and Vernon 1987; Reinhardt and Rubenach 1989; Lang and Dunn 1990; Phillips and Key 1992; Rubenach 1992; Williams 1994; Karlstrom and Williams 1995).

Most of these studies concluded that porphyroblast nucleation and growth occurred rapidly relative to cleavage development. Williams $(1994$, p.1) was also able to conclude that "...fabric development and porphyroblast growth may have been quite rapid, of the order of several hundreds of thousands of years...". Reinhardt and Rubenach (1989) noted that rapid porphyroblast growth may not be consistent with some studies of chemical zoning in garnet from areas recording significant pressure as well as temperature changes. They suggested that rapid growth in the Proterozoic rocks they studied may reflect rapid temperature increases during the early stages of deformation, and therefore fundamentally different $P-T$ - $t$ histories compared to rocks that record extensive uplift or synmetamorphic thrusting. Metamorphism and deformation was also of Proterozoic age in the areas studied by Bell and Rubenach (1983), Rubenach (1992), and Williams (1994). Although the metamorphism studied by Lang and Dunn (1990) was Paleozoic, they suggested that it was closely related to granitoid intrusions. Metamorphism described by Karlstrom and Williams (1995) was Proterozoic and occurred during plutonism. Thus, it appears that very few studies (e.g., Jamieson and Vernon 1987) of this type have been done in a setting where expected thermal gradients might be lower than those in the Proterozoic, or those related to granitoid intrusions.

Reinhardt and Rubenach (1989) assumed that deformation occurred simultaneously over the relatively small area of their study. They went on to suggest that similar microstructural studies on a regional scale may possibly show how deformation and isotherms moved relative to one another across an orogenic belt. Such studies may improve our understanding of the diachronous nature of deformation and metamorphism, but if both deformation and metamorphism migrated through the area, it would be difficult to draw conclusions regarding their relative rates of migration. This is especially true if diachronous plutonism also occurred in the same time interval. Recent work (e.g., Bell and Hickey 1997; Bell et al. 1998) suggests that it may be more difficult to correlate coeval inclusion trails from 


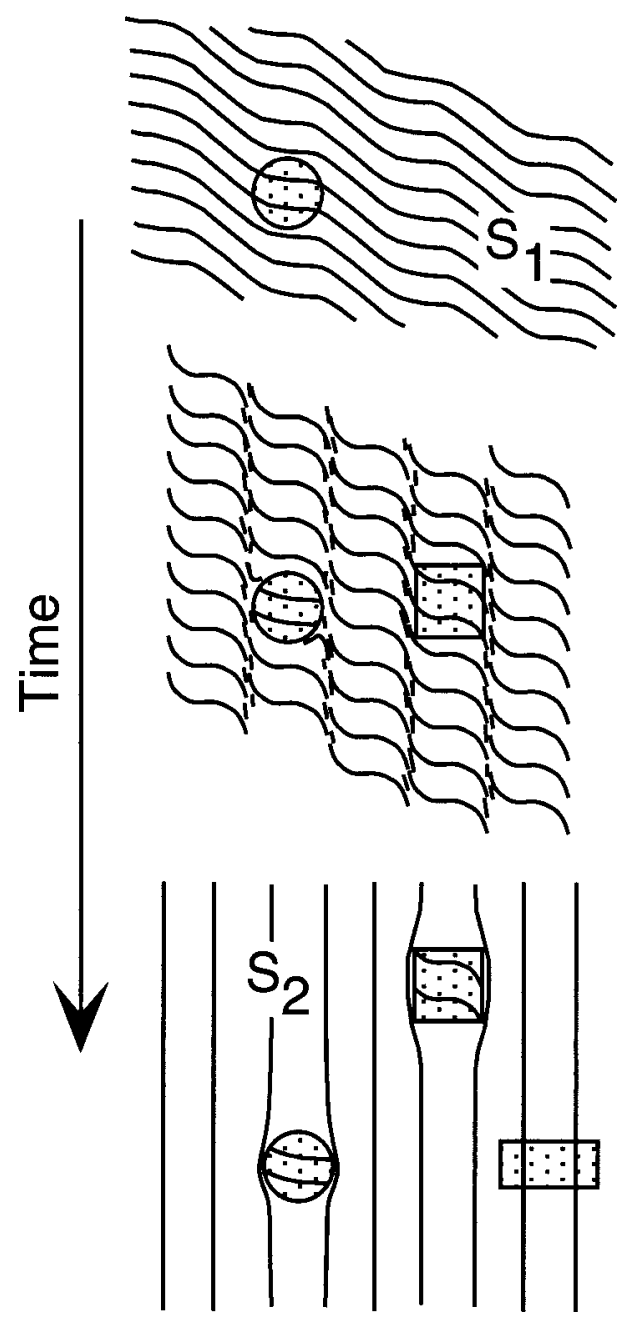

FigURE 4. Diagrams illustrating how different porphyroblast phases (stippled) can preserve different stages of foliation development. The round phase grows first, during the early stages of $S_{2}$ development. The square phase grows next, and finally the rectangular phase overgrows $S_{2}$ late in its development.

sample to sample than previously thought, which may make regional studies of this sort very difficult. By measuring the axes of inclusion-trail curvature in porphyroblasts, these authors have shown that porphyroblasts containing very similar inclusion-trail geometries from sample to sample may have grown at different times. The method they used will be discussed in the section below entitled "Use of linear fabrics preserved in porphyroblasts."

The overall aim of the above studies was to understand better the links between deformation and metamorphism (and sometimes magmatism), and therefore provide a better understanding of the tectono-metamorphic history of mountain belts. These studies demonstrated a close spatial and temporal relationship between deformation and metamorphism, but is there a causal link as well? A causal relationship has been championed by Bell et al. (1986) and Bell and Hayward (1992), who argued that deformation partitioning and crenulation-cleavage development control the timing and locations of porphyroblast nucleation and growth. Although this model has become popular, occasionally it has been questioned or challenged (e.g., Vernon 1989; Passchier et al. 1992; Phillips and Key 1992; Vernon et al. 1992, 1993).

\section{Timing of pluton emplacement relative to deformation and metamorphism}

Plutons are widely used to bracket ages of metamorphism and deformation in orogenic belts, owing largely to the increased availability and precision of radiometric ages for pluton emplacement (Paterson et al. 1991). However, to use these pluton ages, the relative timing between pluton emplacement and regional deformation and metamorphism must first be established, and porphyroblasts that grew in the pluton aureole as a result of emplacement-related contact metamorphism can play an important role in determining the relative timing of these events. Paterson et al. (1991) provided a review of porphyroblast-matrix microstructures in relation to pluton emplacement, and papers by Vernon (1988a), Davis (1993), Karlstrom and Williams (1995), and Morgan et al. (1998) provided examples of this application and the information it can provide. Karlstrom and Williams (1995) emphasized that there are three binary timing relationships in pluton aureoles: (1) deformation and plutonism, (2) plutonism and metamorphism, and (3) metamorphism and deformation. All three of these must be interpreted correctly before a complete understanding of the aureole's tectonothermal evolution can be obtained.

\section{Finite longitudinal strain determinations}

Although absolute strain measurements are critical for studies of mass transport and volume change during deformation (e.g., Goldstein et al. 1998), they are rarely obtainable in deformed metapelitic rocks owing to a lack of appropriate strain markers. Porphyroblasts have been treated as passive markers (e.g., Sanderson and Meneilly 1981), but such studies assume specific rotational behavior of the porphyroblasts, which is a topic of considerable debate (discussed in next three sections). Alternatively, at least two methods can be used to quantify finite longitudinal strains in porphyroblastic rocks and, although these methods cannot directly quantify shortening strains, they do not rely on assumptions regarding porphyroblast kinematics.

(1) In the first method, extensions are measured using brittlely segmented porphyroblasts such as kyanite or tourmaline (e.g., Ramsay and Huber 1983). The total length of a segmented crystal is used as the final length, and the individual segment lengths are combined to arrive at the initial length. Such measurements generally underestimate the total extension because they cannot account for matrix strains that predate the brittle segmentation; nor can they fully account for intracrystalline deformation of the porphyroblasts.

(2) The second method, recently described by Johnson and Williams (1998), makes use of oppositely concave microfolds that formed by heterogeneous extension of the matrix around porphyroblasts (Johnson and Bell 1996; Johnson and Moore 1996). A measure of extension is obtained by comparing the spac- 
ing of two foliation surfaces measured within a porphyroblast with the spacing of the same two foliation surfaces measured in the matrix (Fig. 5). Many syndeformational porphyroblasts appear to have grown relatively early during deformation (e.g., Bell et al. 1986; Vernon 1989; Bell and Hayward 1991), and in these instances the method can provide a close estimate of the absolute extension (Johnson and Williams 1998). This method is particularly suited to metapelites, and two published examples to which it might be successfully applied are those of Passchier and Speck (1994) and Aerden (1995).

\section{Kinematics and porphyroblast rotation}

Introduction. Porphyroblasts containing sigmoidal or spiral-shaped inclusion trails are common in deformed metamorphic rocks, and appear on initial investigation to be ideal kinematic indicators (Fig. 6). They are commonly interpreted as having rotated with respect to a foliation fixed to the flow plane during simple shear or a general non-coaxial flow (e.g., Turner 1948; Spry 1963; Rosenfeld 1968, 1970; Schoneveld 1979; Christensen et al. 1989; Passchier et al. 1992; Gray and Busa 1994; Williams and Jiang 1999), but some workers have pointed out that, during coaxial deformation histories, porphyroblasts may remain "static" while the matrix fabric rotates around them (e.g., Ramsay 1962; Kennan 1971; Wilson 1971; Fyson 1980). Although less commonly described, porphyroblasts with straight, or slightly curved inclusion trails have also been interpreted as having rotated relative to a foliation fixed to a flow plane during simple shear or a general noncoaxial flow (e.g., Schoneveld 1979; Olesen 1982; Barker 1994). Research over the past two decades suggests that the formation of sigmoidal trails owing to a shear couple between the porphyroblast and the surrounding foliation may be an oversimplified model (e.g., Bell 1985; Johnson 1990a; Bell et al. 1992; Vernon et al. 1993; Passchier and Speck 1994; Williams 1994; Aerden 1995; Johnson and Vernon 1995a; Hickey and Bell 1999). The topic of porphyroblast rotation has generated considerable debate, and interested readers are referred to the following paired papers for contrasting interpretations and/or

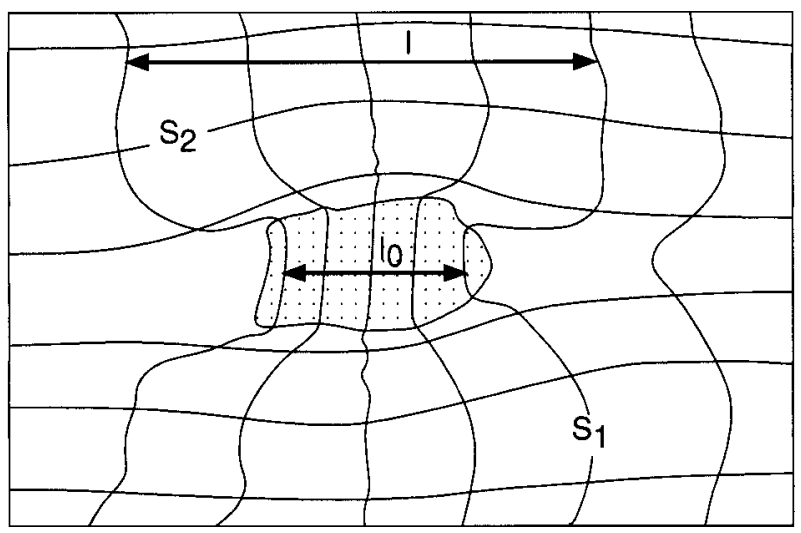

FIGURE 5. Diagram illustrating oppositely concave microfolds on either side of a porphyroblast (stippled). Heavy lines show how measurements are made to calculate elongation: e $=\left(1-1_{0}\right) / 1_{0}$. After Johnson and Williams (1998). discussions: Bell et al. (1992) and Passchier et al. (1992); Visser and Mancktelow (1992) and Forde and Bell (1993); Busa and Gray (1992) and Hickey and Bell (1999); Johnson (1993a) and Williams and Jiang (1999); Vernon et al. (1993) and Bell and Hickey (1999).

Discussions of porphyroblast rotation or non-rotation should specify a reference frame (Williams and Jiang 1999), the choice of which is arbitrary. For example, to test whether or not porphyroblast inclusion trails are consistently oriented over a large, multiply deformed area, geographical coordinates or some other spatially fixed external reference frame may be appropriate. Alternatively, to test the relationships between measured inclusion-trail orientations against those predicted by different folding models, the average axial surface of a fold may be an appropriate reference frame. In such a case, the relative timing between porphyroblast growth and fold development should be demonstrable.

Porphyroblasts and crenulation cleavage. Porphyroblasts are commonly found in close spatial and temporal association with crenulation cleavage (Fig. 7; e.g., Zwart 1962, 1979; Schoneveld 1979; Williams and Schoneveld 1981; Bell and Rubenach 1983; Vernon 1988b; Lang and Dunn 1990; Passchier and Speck 1994; Williams 1994; Aerden 1995; Johnson and Moore 1996). Consequently, Johnson (1993a) suggested that the kinematic origin of sigmoidal or spiral-shaped inclusiontrail geometries may be understood better by evaluating the kinematics of crenulation-cleavage development. Several different hypotheses have been presented concerning the sense of shear, if any, along developing crenulation cleavages (e.g., Hobbs et al. 1976; Gray 1979; Bell 1981; Williams and Schoneveld 1981; Johnson 1990a, 1993a; Bell and Johnson 1992; Rajlich 1993; Stewart 1997). The true sense of displacement along a developing crenulation cleavage can be tested

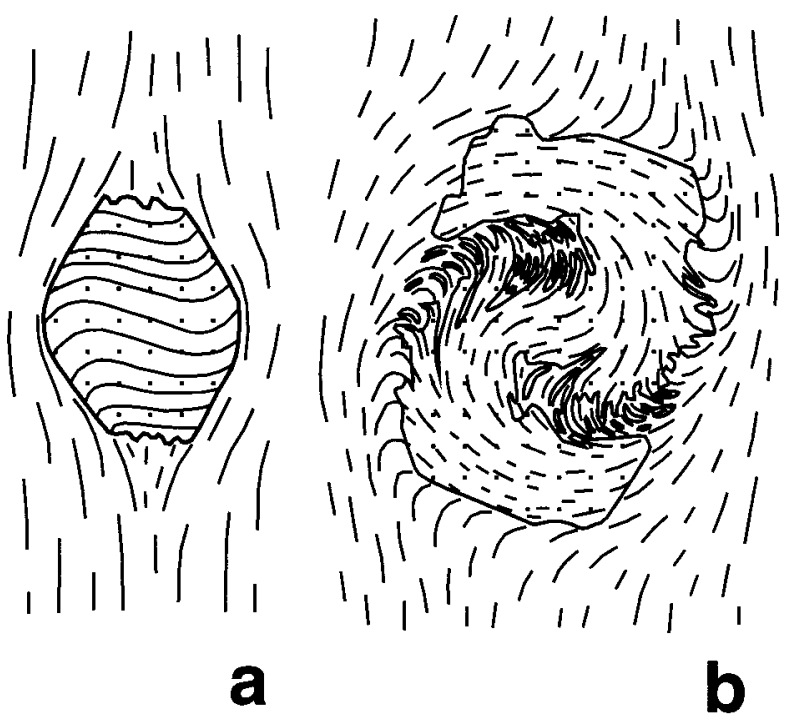

FigURE 6. Diagrams illustrating (a) sigmoidal and (b) smoothly curving spiral-shaped inclusion trails, surrounded by a single matrix foliation. Both geometries, and particularly (b), might be interpreted as forming by clockwise rotation of the porphyroblasts relative to a flow plane of simple shear parallel to the external foliation. 


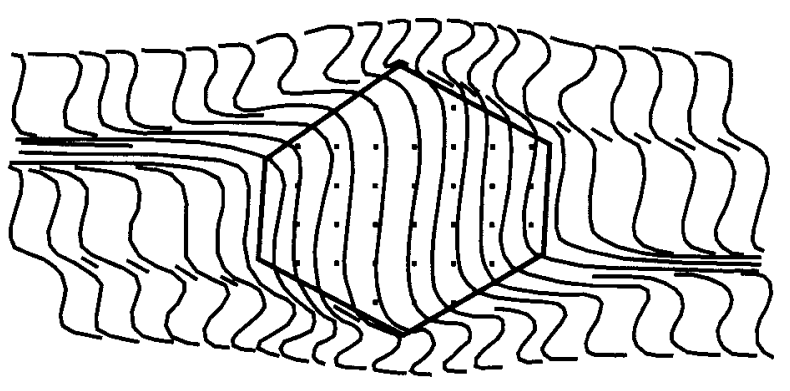

FIGURE 7. Sigmoidal inclusion trails preserved in a porphyroblast (stippled) that grew during the development of a crenulation cleavage.

unambiguously using examples in which the cleavage cuts two pre-existing marker surfaces with opposite vergence (Fig. 8). Studies documenting true displacements are rare (e.g., Stewart 1997), and recent work suggests that a more careful evaluation of the relationships between porphyroblasts and crenulation cleavage is warranted. For example, Johnson (1999a) showed that foliations in the microlithons of some crenulations rotate in the opposite direction to micas in the septa, relative to the developing crenulation cleavage (Fig. 9). In these same rocks, porphyroblast inclusion trails are commonly parallel to the foliations in the microlithons (Fig. 9). If these porphyroblasts pre-dated, or grew syncronously with, development of the crenulation cleavage, they must have rotated passively with the foliation in the microlithons. Such a "back-rotation" mechanism implies that shearing and associated displacement occur in the septa, where two microlithons rotate past one another (Fig. 9).

Passive rotation of porphyroblasts during folding. Many studies have focussed on whether or not porphyroblasts rotate owing to a shear couple between the porphyroblasts and a surrounding matrix foliation. However, three recent studies have argued for passive porphyroblast rotation with fold limbs (e.g., Fig. 10) during macroscale folding (Kraus and Williams 1998; Solar and Brown 1999) or pluton emplacement (Morgan et al. 1998). Further studies of this sort would be valuable, particu- larly if inclusion-trail orientation data could be gathered from both limbs of a well-exposed macroscale fold unaffected by deformation events that post-date porphyroblast growth. Other recent studies (e.g., Bell and Hickey 1997; Bell et al. 1997, 1998) have analysed the orientations of linear fabrics in porphyroblasts around macroscale folds, rather than inclusion-trail orientations, and have argued for lack of porphyroblast rotation (passive or otherwise); this will be discussed in the section below entitled "Porphyroblasts and folding mechanisms."

Spiral-shaped inclusion trails. Porphyroblasts with spiralshaped inclusion trails are found in a wide range of deformation environments, from zones dominated by a single foliation to multiply folded and foliated schist belts. Building on the work of Rosenfeld (1970), Powell and Vernon (1979) and Schoneveld (1977, 1979), considerable effort has been made over the last decade to understand the formation of spiral-shaped inclusion trails (Fig. 6; e.g., Bell and Johnson 1989; Masuda and Mochizuki 1989; Hayward 1992; Johnson 1993a, 1993b; Bjørnerud and Zhang 1994; Bell et al. 1998; Williams and Jiang 1999). There are currently two models for the development of spiral trails: (1) a "rotational" model in which porphyroblast growth occurs during rotation relative to a foliation fixed to the flow plane of simple shear; and (2) a "non-rotational" model in which porphyroblast growth occurs during the development of successively overprinting, near-orthogonal foliations/crenulation cleavages. The review by Johnson (1993a) concluded that neither of these models could be ruled out entirely on the basis of geometry alone. Most recently, Williams and Jiang (1999) stated that geometries observed in sections through porphyroblasts cut parallel to the spiral axes prove that spiral-shaped inclusion trails form by the rotational model. However, published sections through porphyroblasts with spiral-shaped inclusion trails may show geometries that Williams and Jiang (1999) claim are diagnostic of non-rotation. For example, Figure 4g of Johnson (1993b), included here as Figure 11, shows microfolds very similar to those in Figure 6c, section $\mathrm{R} / 2$ of Williams and Jiang (1999).

Whether or not these microfolds correspond directly to those shown by Williams and Jiang (1999), they are not possible in any section of the rotational model recommended by these authors; however, such microfolds are a natural result of the non-

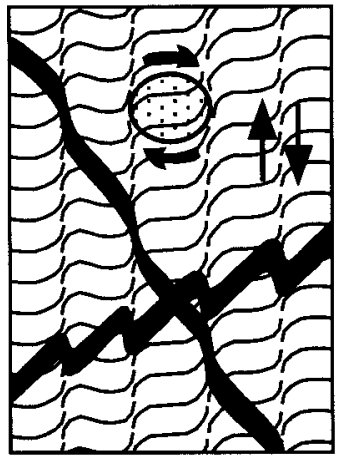

a

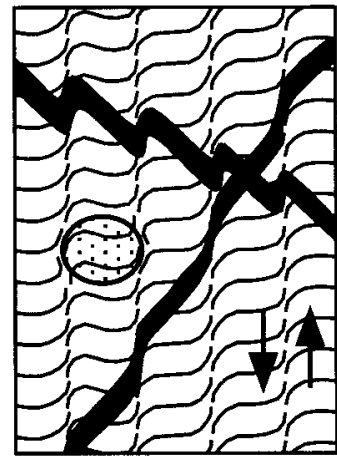

b

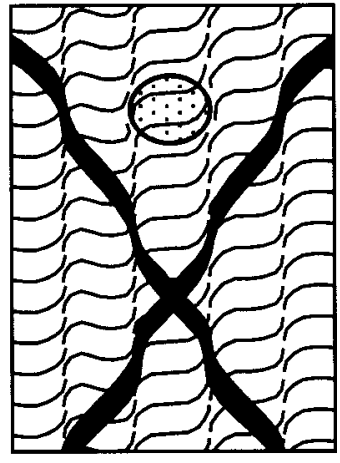

C
FIGURE 8. Diagrams showing possible relationships between sigmoidal inclusion trails, crenulation-cleavage morphology and sense of displacement on the crenulation cleavage. The two dark bands in each diagram represent cross-cutting veins, or bedding and one cross-cutting vein. (a) Porphyroblast undergoes clockwise rotation, and displacement of vein sets confirms dextral shear sense on the cleavage. (b) Porphyroblast does not rotate, and displacement of vein sets confirms sinistral shear sense on the cleavage. (c) Porphyroblast does not rotate, and all displacement is apparent, caused by dissolution of the veins along the developing cleavage. After Johnson (1993a). 


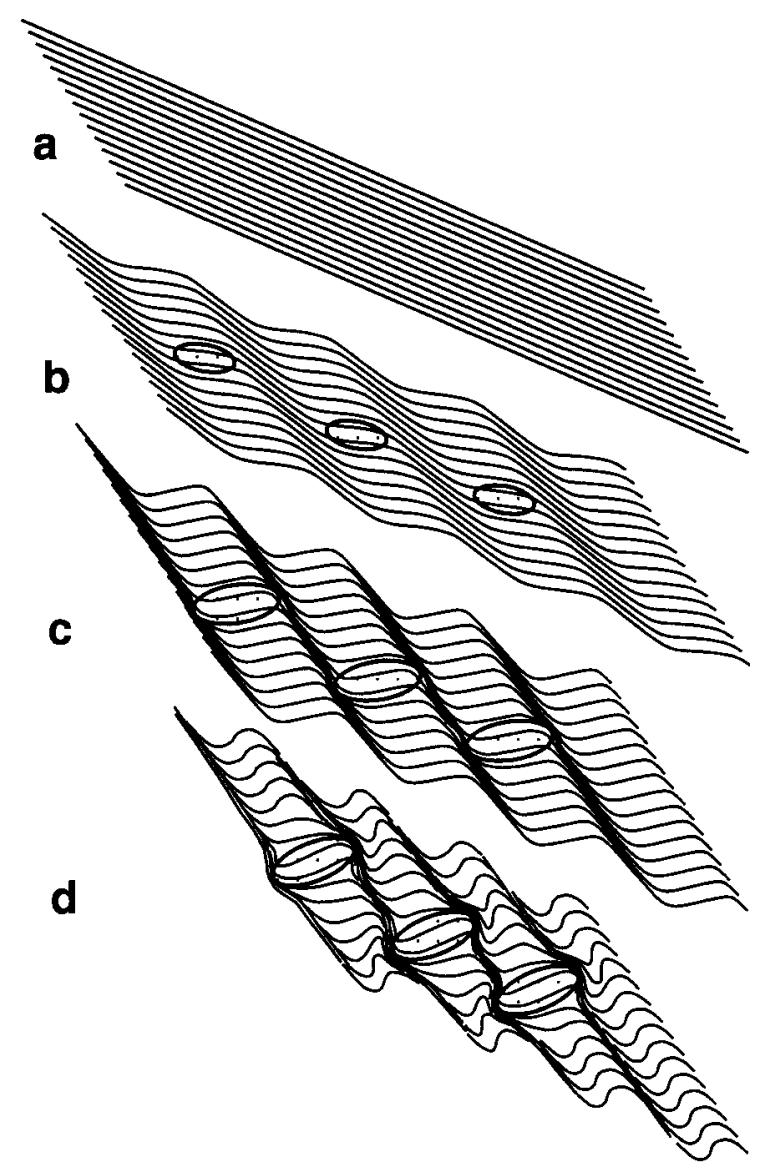

FIGURE 9. Sequence showing porphyroblast rotation relative to a developing crenulation cleavage. In this example, the enveloping surface to the foliation being crenulated remains parallel in all stages of the sequence, but many variations are possible. Micas in the septa rotate clockwise relative to the developing crenulation cleavage, whereas the foliation in the microlithons (Q-domains) rotates counterclockwise. Porphyroblasts that grew during crenulationcleavage development are shown rotating passively with the foliation in the microlithons. When this foliation (and porphyroblast inclusion trails) becomes orthogonal to the developing crenulation cleavage, microlithon (and porphyroblast) rotation stops. After Johnson (1999a).

rotational model. The rotational model should not be rejected on the basis of these observations because, as Johnson (1993a) emphasized, both the rotational and non-rotational models can be modified in various ways to account for specific geometries that are not predicted by these models in their simplest forms. For example, the assumption made by Williams and Jiang (1999) regarding how the matrix deforms around a growing porphyroblast is the main reason why their non-rotational model does not show geometries similar to the rotational model in axis-parallel sections. The original non-rotational model presented by Bell and Johnson (1989) requires the developing foliation/crenulation cleavage to begin wrapping around the porphyroblast at an early stage of its growth, owing to heterogeneous shortening, rather than remaining planar throughout

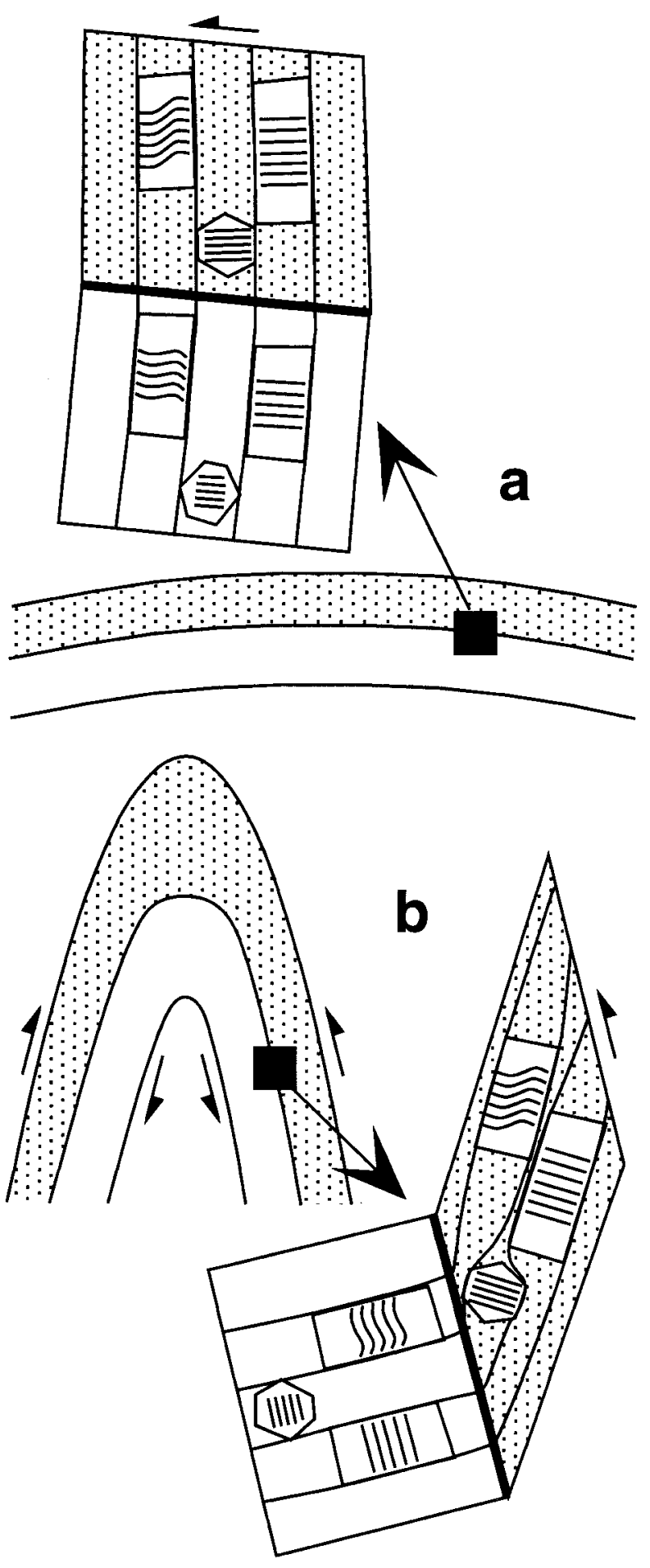

Figure 10. Schematic summary showing passive rotation of porphyroblasts with fold limbs during folding. Porphyroblasts grow early during folding (a), and as the fold is amplified (b) the porphyroblasts rotated passively by different amounts depending on whether they were in the pelitic (stippled) or psammitic layers. However, porphyroblasts do not rotate relative to the axial-surface foliation in either layer. After Kraus and Williams (1998). 

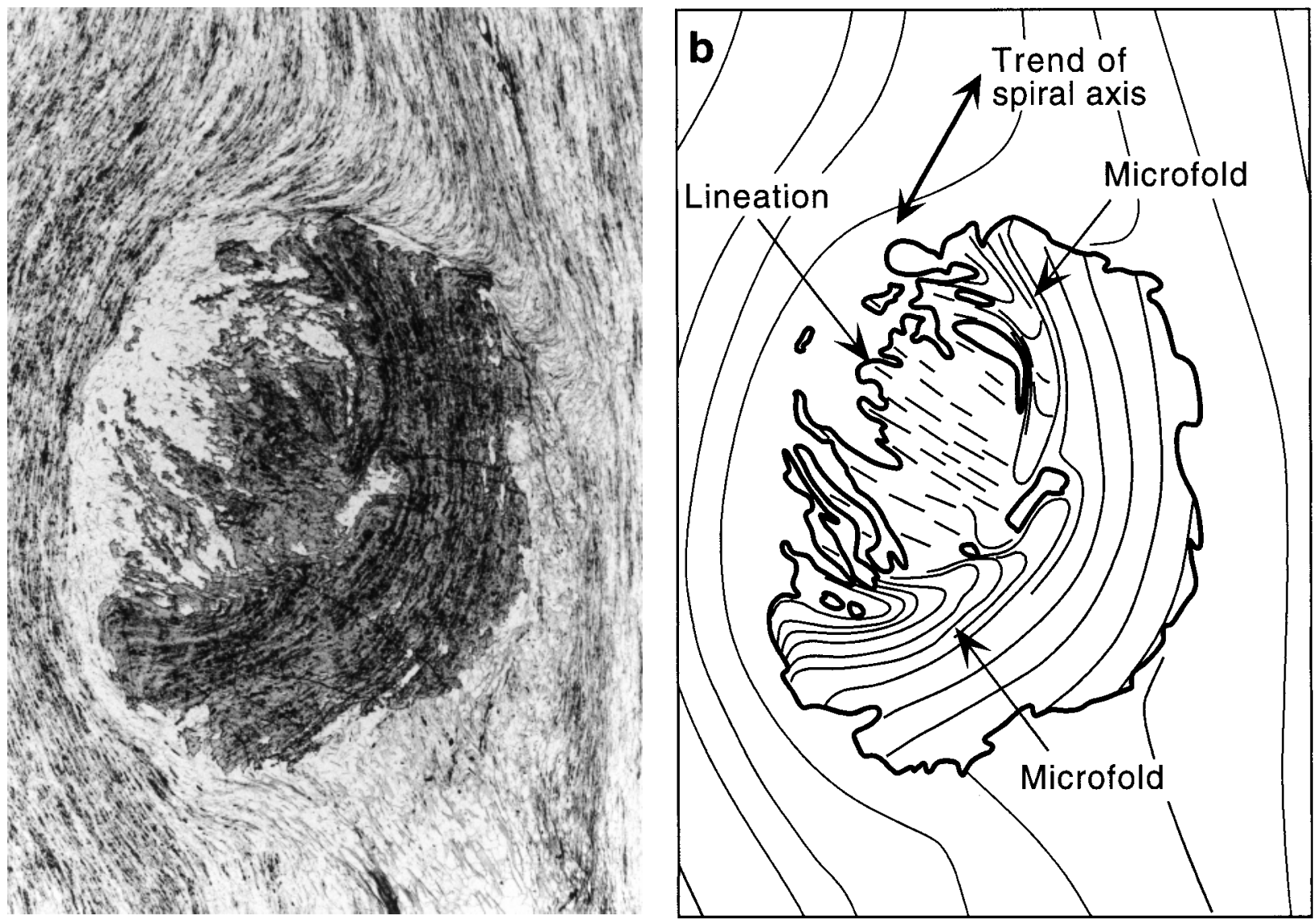

FIGURE 11. Photomicrograph (a) and line diagram (b) of a garnet porphyroblast and surrounding matrix. From one of eight serial thin sections cut parallel to the spiral axis through a single garnet porphyroblast containing spiral-shaped inclusion trails; this section is near the porphyroblast margin. Center of porphyroblast lies above the plane of the paper, and if viewed parallel to the spiral axis, from the base of the page, the spiral would open in a counterclockwise direction from core to rim. [See Johnson (1993b, Fig. 4) for full serial set.] What remains of the inner part of the porphyroblast in this section contains a foliation that is nearly parallel to the section plane, and a mineral elongation lineation is present on this surface. The outer part of the porphyroblast (to the right) contains an arcuate foliation that wraps around the inner part, and intersects the thin section at a moderate angle. Where the foliations in these two parts of the garnet come together, they form a microfold that changes plunge from one side of the garnet to the other. Outward-opening microfolds of this type are not possible in any section of the rotational model for spiral trail development. Plane polarized light, long axis of photomicrograph subhorizontal, $12.75 \mathrm{~mm}$.

the entire growth phase as assumed by Williams and Jiang (1999). Consequently, the matrix around the porphyroblast is stretched heterogeneously - a process clearly illustrated in the serial-section study of Johnson and Moore (1996). This heterogeneous stretching causes the crenulation folds in the matrix to be non-cylindrical, doubly curved surfaces before they are overgrown by the porphyroblast. This one simple, but realistic modification leads to closed-loop geometries in appropriate axis-parellel sections, as observed in the rotational model, rather than the simple deflected foliation patterns predicted by Williams and Jiang (1999).

An important future study would involve serial sectioning of garnet porphyroblasts with spiral-shaped trails, parallel to their spiral axes. I am aware of only one such study to date (Johnson 1993b), which involved garnet porphyroblasts with smoothly curving trails. Future serial-section studies could evaluate porphyroblasts with both smoothly curving and discontinuous spiral-shaped trails, thus addressing the microstructural complexities illustrated in many recent studies (e.g., Bell and Johnson 1989; Bell and Hayward 1991; Hayward 1992; Bell and Hickey 1997; Bell et al. 1998). In light of the results of Williams and Jiang (1999), such a study may help resolve the debate over how spiral-shaped inclusion trails form. This debate illustrates the fact that geometries alone rarely provide unequivocal information about strain histories, and highlights the possibility that different spiral-shaped inclusion geometries may form by different mechanisms during different deformation histories. However, regardless of how they form, these inclusion trails have played an increasingly important role in a range of studies, which will be discussed in the next section and a later one entitled "Inferring shear-strain rates from prophyroblast growth rates." 
Use of linear fabrics preserved in porphyroblasts

A recently emphasized approach to using porphyroblast microstructures involves determining the three-dimensional orientations of relative rotation axes in porphyroblasts that contain sigmoidal, spiral-shaped, and other complex inclusion-trail geometries (e.g., Fig. 12). This technique was first described in detail by Rosenfeld (1970), and a modified version was subsequently presented by Hayward (1990) and Bell et al. (1995). These axes have been referred to by various names, including rotation axes, spiral axes, relative rotation axes, fold axes, microfold axes, foliation intersection axes, and foliation intersection/inflexion axes. In keeping with the most popular current usage (e.g., Bell et al. 1995, 1998; Bell and Hickey 1997, 1999; Hickey and Bell 1999), foliation intersection/inflexion axes, or "FIA," will be used here. To measure FIAs in three dimensions, several vertical thin sections are required to determine their trend (Fig. 12a), and a separate set of thin sections that fan through the horizontal is required to determine their plunge. Figure 12a shows a simple case in which the porphyroblasts contain only one FIA, but some porphyroblasts that have grown episodically preserve two or more FIA sets (e.g., one preserved in the porphyroblast core, and another preserved in the rim). The same technique for determining FIAs can be applied to these more complex porphyroblast microstructures (Fig. 12b).

FIA data sets have thus far been used to: (1) propose geometrical relationships between regional folding events and porphyroblasts inferred to have rotated (Rosenfeld 1968, 1970); (2) help constrain the mechanisms and relative timing of pluton emplacement (Davis 1993); (3) evaluate folding mechanisms and argue against porphyroblast rotation relative to an externally fixed reference frame (e.g., Bell and Hickey 1997; Hickey and Bell 1999); (4) argue for complex structural histories in rocks with a structurally simple matrix (Bell and Hickey 1999); and (5) argue that these axes are orthogonal to convergence vectors of converging tectonic plates during orogenesis, and therefore that they can be used to reconstruct plate motions (Bell et al. 1992, 1995, 1998). Studies involving FIAs have the advantage that such axes should form in the same orientation, whether or not the porphyroblasts rotate relative to a foliation fixed to a flow plane. Thus, focussing on FIAs, rather than inclusion-trail orientations, may partly diffuse the controversy over porphyroblast kinematics. However, FIAs in porphyroblasts may be reoriented after porphyroblast growth, for example by passive rotation of porphyroblasts during folding, but this will be discussed in the next section (also see previous section).

FIA studies represent a relatively new trend in microstructural analysis, and so clarification is still required on certain aspects of the research. Following are four aspects that could be addressed in future studies. (1) Any FIAs that form around a preexisting porphyroblast core must be curved (Hayward 1990), and so their orientations will vary, depending on the shape of the porphyroblast, the size of the porphyroblast relative to the scale of deformation partitioning, and where the porphyroblast is intersected by a thin section. Hayward (1990) estimated that FIA spreads owing to curvature effects should typically be up to $\pm 20^{\circ}$. Can the effects of this curvature on measured FIA ori-

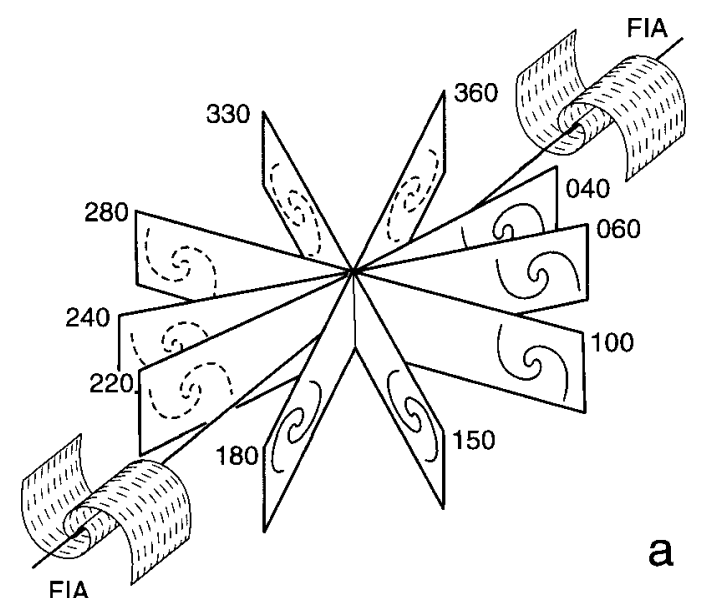

FIA

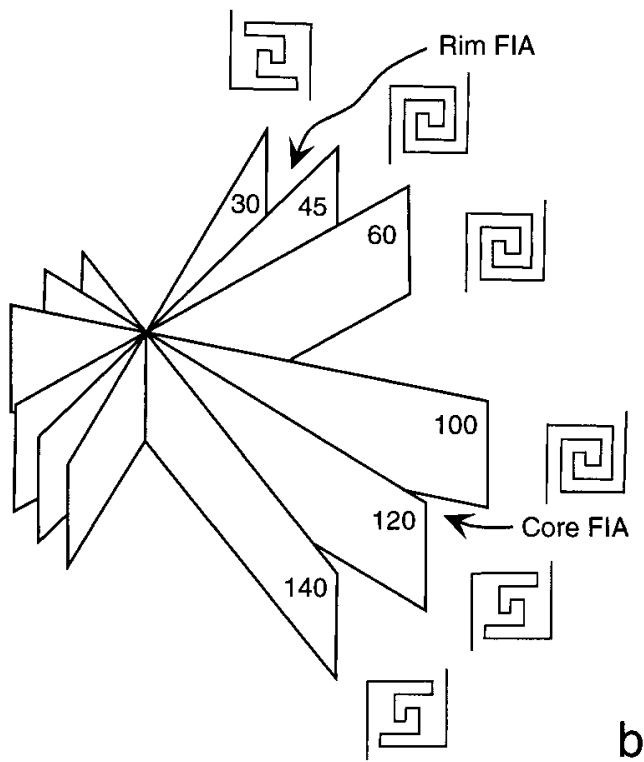

FIGURE 12. Diagrams showing the method by which the trends of foliation intersection/inflexion axes (FIA) are measured. Vertical thin sections are systematically cut through a rock until the asymmetry of inclusion trails changes between two thin sections. The angular difference between these two thin sections determines a trend-range of the FIA. An addition set of thin sections that fan through the horizontal would be required to measure the plunge-range of FIAs. (a) Example of single FIA after Hickey and Bell (1999). (b) Example of one FIA in porphyroblast cores, and a second in porphyroblast rims, after Bell and Hayward (1991).

entations be quantified more precisely, and so possibly lead to a standard set of errors that can be applied to such measurements? (2) Microstructural complexity and inclusion-trail quality vary from sample to sample, and so the level of accuracy in the interpretations may also vary. Yet, most measured FIAs are presented with the same $\pm 5^{\circ}$ accuracy. How do we differentiate between highly reliable FIA determinations and those that may be less reliable? (3) The current method (Fig. 12) precludes the possibility of demonstrating in a single porphyroblast that all determined axes are in fact unique and separate, and what their geometrical relationships are in three dimensions. 
This could be attempted using standard serial thin-sectioning techniques (e.g., Johnson 1993b); however, if more than one FIA-set is present in a porphyroblast, constructing a three-dimensional model would be challenging owing to the difficulty of correlating specific inclusion surfaces from one section to another. Recent advances in the application of computed Xray tomography to rocks (e.g., Ketcham and Carlson 2000 [Editor's note: see also Brown et al., this volume]) may provide a simpler and more versatile solution. (4) The current method precludes the accurate determination of FIA orientations in numerous individual porphyroblasts from single samples. Such determinations could resolve whether spreads in FIA orientations are entirely the result of curved FIA and inclusion trails, as discussed in (1) above, or partly the result of variation in FIA orientations from porphyroblast to porphyroblast. High-resolution computed X-ray tomography (e.g., Ketcham and Carlson 2000) may provide a useful tool for addressing this problem as well.

When using the method shown in Figure 12, inclusion trails typically switch asymmetry over a range, within which individual thin sections contain porphyroblasts with both clockwise and counterclockwise curvature (Fig. 12). Work is currently in progress (A. Stallard, personal communication, 1999) to determine the range, or spread of FIA orientations in many individual samples. However, it may not be possible to determine which component of this spread reflects the effects of curvature (point 1 above), and which component reflects true sample-scale variation of FIA orientations (point 4 above). Although some issues still need to be resolved, this is an exciting application of porphyroblast microstructures, and the recent data sets are impressive. An example of how FIA orientation data have been used will be discussed in the next section. [Editor's note: see also Bell and Mares, this volume.]

\section{Porphyroblasts and folding mechanisms}

Where porphyroblasts with sigmoidal inclusion trails have grown during a particular folding event, the sigmoids form a "Z" on the left limb of an antiform, and an "S" on the right limb (Fig. 13). This consistent observation has led several investigators to propose the following folding mechanisms or models, which are shown schematically in Figure 13. (1) During flexural slip/flow (Fig. 13a), porphyroblasts rotate in the opposite direction to the bulk rotation of fold limbs, owing to a shear couple between the porphyroblasts and the layering being folded (e.g., Zwart 1960; Powell and McQueen 1976). (2) During slip along an axial-surface cleavage (Fig. 13b), porphyroblasts rotate in the opposite direction to the bulk rotation of fold limbs, owing to a shear couple between the porphyroblasts and the axial-surface cleavage (e.g., Zwart and Oele 1966; Schoneveld 1979). (3) During slip along a crenulated foliation (Fig. 13c), porphyroblasts rotate in the opposite direction to the bulk rotation of fold limbs, owing to a shear couple between the porphyroblasts and the foliation being crenulated (Williams and Schoneveld 1981). (4) During amplification of a flexural slip/flow fold by flattening (Fig. 13d), porphyroblasts may or may not be expected to rotate, depending the timing of their growth relative to folding (e.g., Ramsay 1962; Kennan 1971; Visser and Mancktelow 1992). If porphyroblasts are present during the initial flexural slip/flow folding, these models suggest that they will rotate. Alternatively, if they grow just prior to, or during, the flattening phase of folding, non-equant porphyroblasts are expected to rotate, whereas equant ones are not. (5) During folding by progressive, bulk, inhomogeneous shortening (Fig. 13e), an anastomosing axial-surface foliation accommodates the shearing component of the strain, whereas the "pods" between this foliation accommodate shortening (e.g., Bell 1985, Bell and Hickey 1997). In this model, the porphyroblasts occupy sites of shortening (or no) strain, and do not rotate.

Models 1-3 above (Figs. 13a-13c) require shear-induced rotation of porphyroblasts relative to the surface defining the flow plane. Porphyroblast inclusion trails around some folds are consistently oriented, suggesting that any shear-induced rotation must effectively balance the spin-induced rotation caused by rotation of fold limbs in the opposite direction; but how fine must this balance be? Studies in which inclusion-trail orientations in folded rocks have been measured commonly indicate statistically consistent orientations, from sample to sample, over scales ranging from single fold limbs to hundreds of square kilometers (e.g., Fyson 1980; Steinhardt 1989; Johnson 1990a, 1990b, 1992; Bell et al. 1992; Hayward 1992; Bell and Forde 1995). However, individual samples used in these studies commonly show inclusion-trail variations of $40-50^{\circ}$ or more (e.g., Fig. 14). Thus, the data suggest a scale dependency for homogeneity; even though large variations occur from porphyroblast to porphyroblast in single samples, the mean orientations from each sample commonly fall in a narrow range. Consequently, shear-induced and spin-induced rotation of porphyroblasts during folding need not be finely balanced at the scale of individual porphyroblasts, whereas a statistical balance commonly may be achieved at the sample scale. Results from such studies may depend strongly on which rock types are sampled. Porphyroblasts generally grow in metapelites, but the relationships shown in Figure 10 suggest that inclusion-trail orientations may vary significantly from sample to sample if porphyroblast-bearing metapsammites were also available.

Model 5 above (Fig. 13e) requires that porphyroblasts do not rotate relative to the axial-surface cleavage, and so apparently they are not affected by either shear-induced or spin-induced rotation during folding. In such a model, the large variations in inclusion-trail orientations commonly found in individual samples must be explained by variable orientation of the foliation prior to overgrowth by the porphyroblasts (e.g., Bell et al. 1992). This model is extremely difficult to test in most cases, because matrix fabrics are commonly reoriented by deformation during and after porphyroblast growth. Williams and Jiang (1999) suggest that model 5 above may be unlikely for two reasons. First, end-member slip folding, in which the axial surface foliation is a shear plane and the deformation is heterogeneous simple shear, may be unlikely because it should result in similar folds, true examples of which are very rare. Second, end-member slip folding involves no shortening perpendicular to the axial surface, and so such folds may not be expected outside shear zones. However, Bell (1981) has discussed how progressive, bulk, inhomogeneous shortening (model 5 above) differs from heterogeneous simple shear, and 


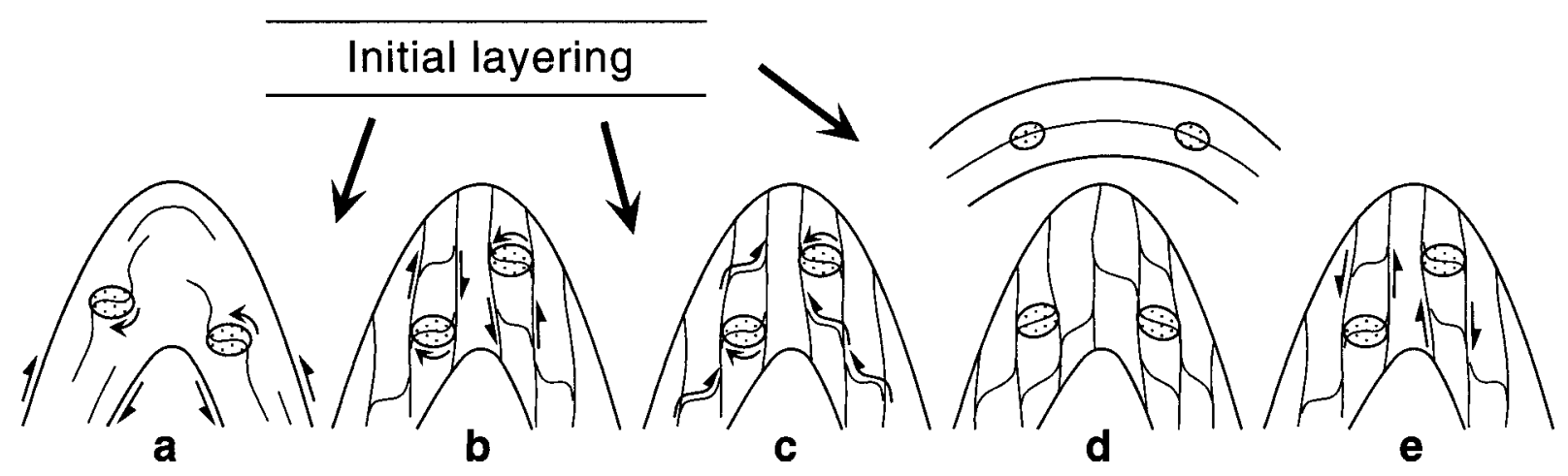

FigURE 13. Five different models that have been proposed to explain the different asymmetry of sigmoidal inclusion trails on the left and right limbs of an antiform. (a) Flexural slip. (b) Slip along an axial-surface cleavage. (c) Slip along the cleavage that is being crenulated. (d) Amplification of initial fold by flattening. (e) Progressive, bulk, inhomogeneous shortening in which slip occurs along the axial-surface cleavage, but the porphyroblasts do not rotate. Note that the sense of shear along the axial-surface foliation in model (e) is opposite to that in model (b).

so the problems with end-member slip folds noted by Williams and Jiang (1999) may not apply.

Williams and Jiang (1999) discussed how vorticity is partitioned during folding of multilayered rocks by end-member pure shear, flexural flow, and slip folding. Their analyses show that, given a particular fold model and vorticity value, a balance can be achieved between shear-induced and spin-induced porphyroblast rotation. This situation can lead to the appearance of little or no porphyroblast rotation relative to the fold axial surface, even though the porphyroblasts were affected by both shear-induced vorticity and spin of the fold limbs. These authors point out that natural folds are generally not end members, and so the final relationships between inclusion-trail orientations and fold development will depend on the relative mix of end-member components. For example, they suggest that a planar anisotropic material shortened parallel to the anisotropy may develop initially by pure shear, followed by flexural flow, and then back to pure shear.

This discussion has returned to the issue of porphyroblast kinematics, and it seems that inclusion-trail geometries and orientations around folds commonly can lend themselves to both rotational and non-rotational interpretations. A promising recent approach to the issue of porphyroblast kinematics during folding was presented by Bell and Hickey (1997), Bell et al. (1997, 1998), and Hickey and Bell (1999), who suggested that the orientations of foliation intersection/inflexion axes (FIA; see previous section) in porphyroblasts should be evaluated, rather than inclusion-trail orientations. Because different FIA sets in these studies have different orientations relative to the axes and axial surfaces of the folds, any rotation of porphyroblasts relative to one another during folding would cause differential spread in the various FIA orientations from one fold limb to the other. The above investigators have argued that multiple FIA sets maintain consistent orientations around macroscale folds, and that these data support the progressive, bulk, inhomogeneous shortening model for folding (model 5 above). However, it may not be possible to rule out models that balance shear-induced and spin-induced porphyroblast rotation during folding to explain the consistent FIA orientations; this is an important topic for future study.

\section{Inclusion-trail orientations and orogenic processes}

A fundamental problem with interpreting the structural development of mountain belts is that foliations and lineations are obliterated continuously, or their orientations greatly disturbed, during progressive or subsequent deformation. Porphyroblast inclusion trails potentially can preserve information about these orientations at the time of porphyroblast growth, but this idea has been a source of major disagreement in the literature because it requires that the porphyroblasts have not been reoriented significantly, relative to one another or some externally fixed reference frame, during or after their growth.

Some studies have documented approximate orthogonality of inclusion trails preserved in porphyroblasts (Figs. 14 and 15; e.g., Bell et al. 1992; Hayward 1992; Johnson 1992; Jones 1994; Aerden 1995), or between inclusion trails and a contemporaneous crenulation cleavage (Fig. 7; e.g., Fyson 1980; Vernon 1988b; Johnson 1990b; Passchier and Speck 1994; Aerden 1994, 1995; Johnson and Vernon 1995a; Johnson and Moore 1996). The inclusion-trail orientations presented for individual samples in some of these studies are highly variable but, remarkably, the average orientation vectors commonly fall within a narrow orientation range from sample to sample (Fig. 14). In many examples, orthogonality is defined by overprinting of steeply and gently dipping foliations (Figs. 14 and 15). A few studies have documented strong variation of inclusiontrail orientations (e.g., Schoneveld 1979; Barker 1994), which may be expected, given the complex and heterogeneous nature of deformation in orogenic belts. However, the occurrence of approximately orthogonal relationships, and particularly alternating steeply and gently dipping inclusion trails, is one of the most intriguing aspects of porphyroblast microstructures, and some possible explanations are presented below.

Bell and Johnson (1989) suggested that steeply and gently dipping foliations preserved in porphyroblasts reflect fundamental dynamic processes of orogenesis. They suggested that an orogenic belt undergoing horizontal shortening and vertical thickening develops a steeply dipping foliation, which may result in a vertical compressive stress $\left(\sigma_{3}\right)$ that exceeds the horizontal compressive stress $\left(\sigma_{1}\right)$ either by crustal overthickening 


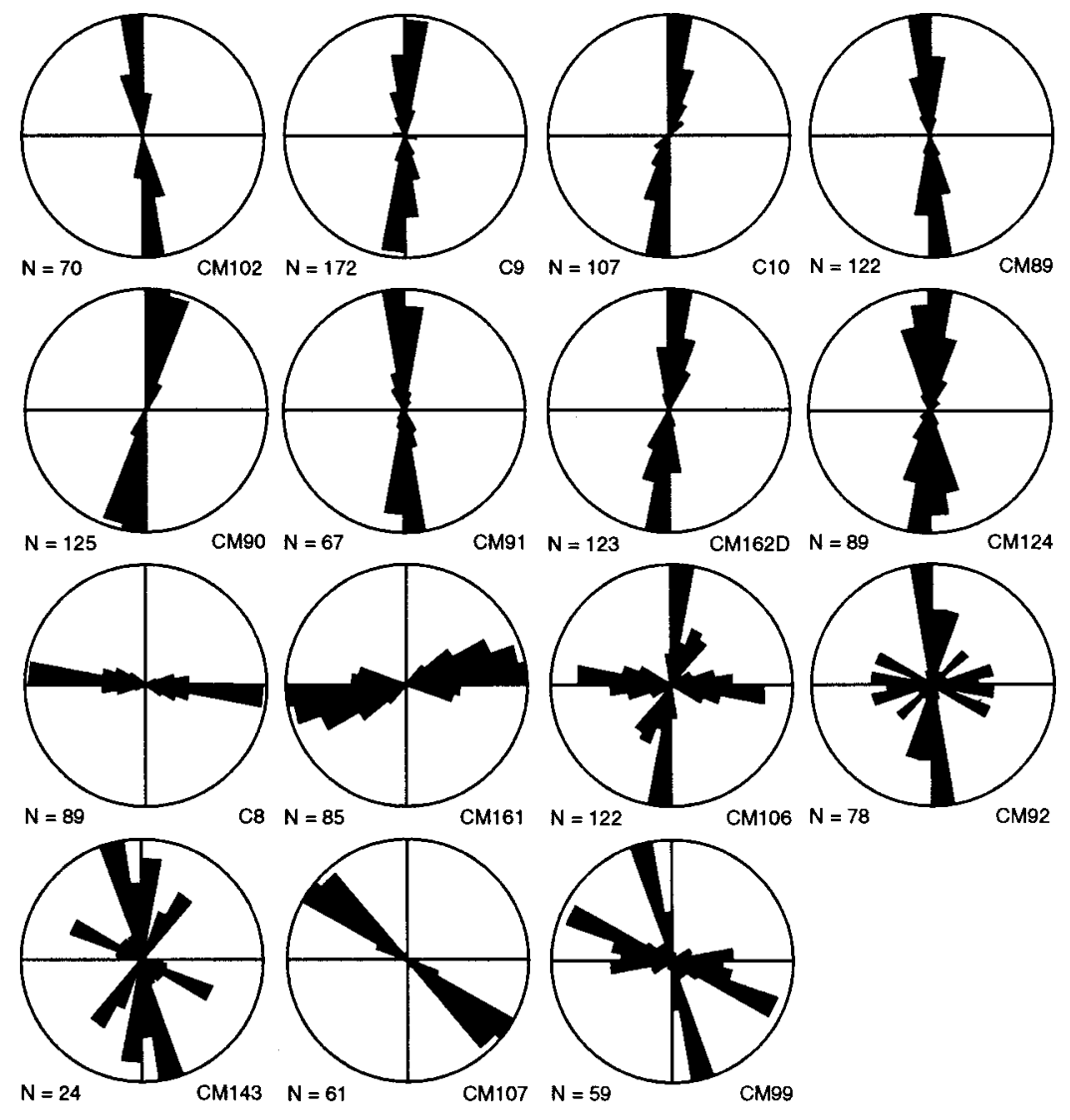

FIGURE 14. Rose diagrams of the rake, or apparent dip, of porphyroblast inclusion trails, measured in at least two vertical thin sections of different strike, from 15 samples collected over an area of $20 \mathrm{~km}^{2}$ in the Cooma Complex, southeastern Australia. Even though most samples show large internal variation, average vectors for the data are remarkably consistent from sample to sample. Eight samples show a peak of steeply dipping inclusion trails, two show gently dipping trails, two (CM 92 \& 106) show both of the above, and the remaining three are different. Johnson (1992) and Johnson and Vernon (1995a) have shown that the porphyroblasts containing steeply and gently dipping inclusion trails grew sequentially, at different times relative to the deformation history. After Johnson (1992). or temporary decay of $\sigma_{1}$. In their model, this reversal in maximum and minimum compressive stresses causes gravitational instability in the core of the orogen, resulting in vertical shortening and a gently dipping foliation that overprints the steeply dipping one. Once gravitational stability is attained in any one area, horizontal shortening can continue to dominate, along with the development of a new steeply dipping foliation. The basic concepts proposed by Bell and Johnson (1989) have been applied to the Otago Schists, New Zealand (Johnson 1990b) and the Variscan Pyrenees, Spain and France (Aerden 1994).

Means (1999) suggested that the gravitational collapse model proposed by Bell and Johnson (1989) may not require a reversal in the directions of maximum and minimum compressive stresses. Instead, the gently dipping foliations may form if the rate of vertical shortening multiplied by $\sigma_{3}$ exceeds the rate of horizontal shortening multiplied by $\sigma_{1}$. This mechanism requires that the rock develops a strong foliation (rheological anisotropy) approximately parallel to $\sigma_{3}$, which slows the rate at which shortening can occur perpendicular to $\sigma_{1}$ and provides an opportunity to meet the condition $\sigma_{1}\left|\dot{e}_{1}\right|<\sigma_{3}\left|\dot{e}_{3}\right|$. Means referred to this as a "reversal" of structural development, and suggested that the gently dipping foliation may play the role of weakening the strong anisotropy so that horizontal shortening and formation of a steeply dipping foliation can continue.

Foliations superposed at high angles to one another have been documented in thrust environments (e.g., Mitra and Yonkee 1985; Helmstaedt and Dixon 1980; Beutner et al. 1988). Beutner et al. (1988) suggested that steeply dipping foliations may form when the rocks undergo layer-parallel shortening as they move over a ramp, and gently dipping foliations may form when the hanging-wall rocks are positioned above a flat. For this explanation to be widely applicable in the context of the present discussion, flat-ramp geometries would need to be common in the middle crust of developing orogens, where porphyroblasts and near-orthogonal relationships are generally found.

Some workers have proposed that gently dipping foliations may form above rising diapirs. In the Pyrenees, for example, a gently dipping crenulation cleavage overprints a steeply dipping foliation above and around several of the granite- or orthogneiss-cored massifs (e.g., Zwart 1979; Soula 1982; Pouget 1991; Vissers 1992; Aerden 1994). Some workers have interpreted the dome-shaped enveloping surface of the crenulation cleavage over the massifs as indicating vertical shortening caused by diapiric rise of the massifs (e.g., Soula 1982; Pouget 1991), whereas others attribute the cleavage to vertical shortening around the massifs during more widespread orogenic collapse (e.g., Vissers 1992; Aerden 1994).

Although the existing inclusion-trail orientation data are still too few to draw firm conclusions, they may well reflect largescale deformation processes in orogenic belts (Johnson 1999b). 

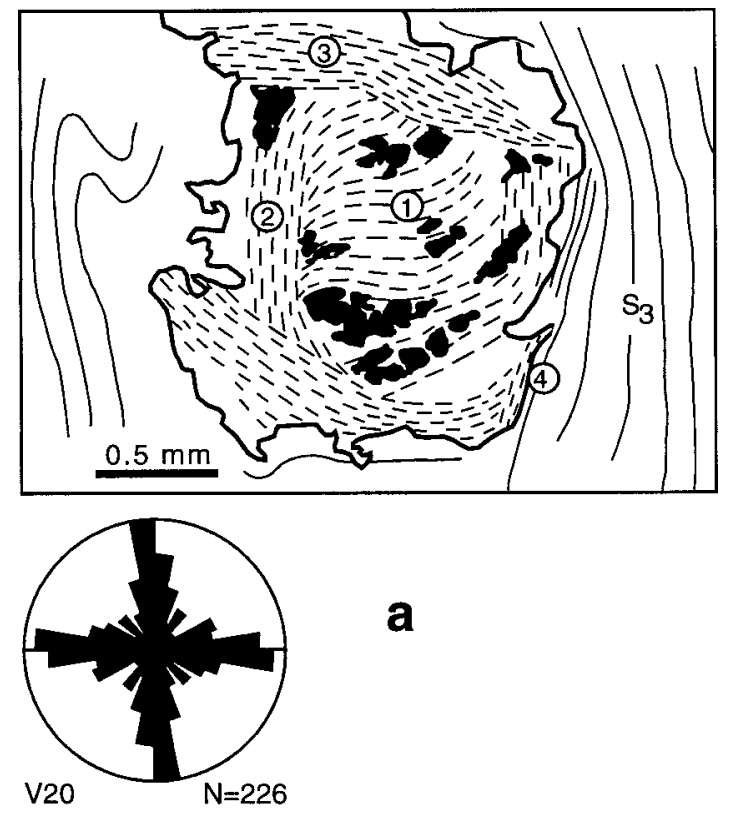

a

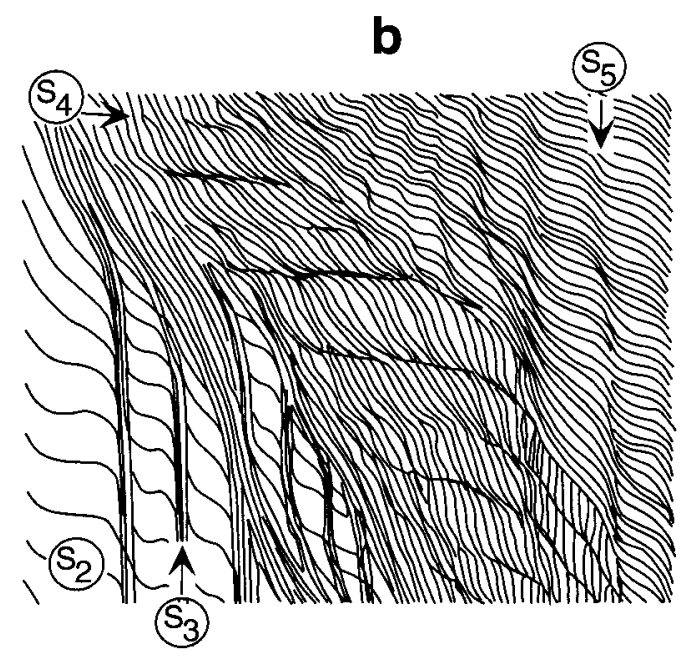

FiguRE 15. (a) Diagram of garnet porphyroblast with four sets of inclusion trails. Accompanying rose diagram shows the rake, or apparent dip, of inclusion-trail sets in numerous garnet porphyroblasts (such as the one illustrated) in a single sample. Measurements were made from at least two differently oriented vertical thin sections, and inclusion-trail sets are statistically steeply and gently dipping. (b) Schematic representation of microstructures from the same area where porphyroblast in (a) was collected, showing four separate foliations/ crenulation cleavages that are successively orthogonal to one another. S3 corresponds to S3 in (a). Both (a) and (b) after Hayward (1992).

Additional data sets are required, and it would be useful if more studies could: (1) document areas where inclusion-trail orientations are highly variable, and evaluate whether or not this is due to rotation of the porphyroblasts relative to one another, or to porphyroblast growth over variably oriented foliations; (2) discuss how histories that involve porphyroblast rotation can result in approximately orthogonal relationships over sizeable areas; and (3) evaluate the kinematics of crenulation-cleavage devel- opment, because processes like the one shown in Figure 9 could explain many orthogonal relationships between different inclusion-trail sets, and between inclusion trails and matrix foliations.

\section{Inferring shear-strain rates from prophyroblast growth rates}

Growth rates of garnet porphyroblasts have been determined from $\mathrm{Rb}-\mathrm{Sr}$ (Christensen et al. 1989, 1994) and U-Pb (Vance and O'Nions 1992) isotopic zonation in single crystals. For porphyroblasts that contain sigmoidal or spiral-shaped inclusion trails, these authors assumed a simple shear deformation history, calculated the total amount of apparent porphyroblast rotation, and combined this information with the total growth time of the porphyroblast to determine a shear-strain rate during garnet growth. Remarkably, all three studies calculate shearstrain rates between $1.3 \times 10^{-14} / \mathrm{s}$ and $2.4 \times 10^{-14} / \mathrm{s}$, which lie within ranges inferred from geological and theoretical studies (e.g., Pfiffner and Ramsay 1982; England 1987; Paterson and Tobisch 1992). The consistency of these results is somewhat surprising for the following reasons.

(1) The method assumes a perfect shear couple between the growing porphyroblast and surrounding matrix, which allows the porphyroblast to rotate in exact accord with the bulk shear strain at the scale of consideration. This seems unlikely given: (a) evidence for fluid pressure at or above lithostatic load, and pockets of fluid located along some grain boundaries (e.g., Vernon 1976, p. 53-56; Etheridge et al. 1983, 1984); (b) dissolution of quartz along some porphyroblast margins, which allows local volume loss to accommodate strain (e.g., Bell et al. 1986); (c) concentration of phyllosilicates, fibrous sillimanite, or graphite along some porphyroblast margins, which may slip easily along their grain boundaries and layered crystallographic structure (Bell et al. 1986; Vernon 1987); and (d) general heterogeneity of strain, which is likely to preclude a one-to-one correlation between bulk shear strain (at whatever scale) and the shear stress transmitted (coupled) to the porphyroblast margin.

(2) Simple shear (a two-dimensional deformation) has boundary discontinuity problems (e.g., Bell 1981) and may be relatively uncommon in the geological record (e.g., Pfiffner and Ramsay 1982; Flinn 1994). During a more general noncoaxial deformation history, an approximately equant, rotated garnet porphyroblast would generally record only the shear component of the strain. Thus, the total strain, and therefore the strain rate, would be underestimated.

(3) The method described above apparently requires continuous and constant crystal growth over the entire growth/deformation interval being measured. Although some garnet porphyroblasts may have grown this way, a wealth of textural and chemical evidence suggests that many garnet porphyroblasts grow episodically, in some cases during more than one deformation (e.g., Karabinos 1984; Rice 1984; Bell and Hayward 1991; Jones 1994; Spiess and Bell 1996).

Regardless of these concerns, the method appears to hold promise, particularly given the advent of in-situ age determinations (discussed in following section). It would be useful for future rate studies to: (1) evaluate the microstructural evidence in the porphyroblasts used, and illustrate this evidence with 
photomicrographs; and (2) discuss the validity of the assumed deformation history (i.e., simple shear). A study that might be particularly interesting would be to apply this method to several porphyroblasts from a single rock, which show a wide range of apparent rotations in their median sections. Variations in isotopic zonation could be compared with the variations in apparent rotations, and if the results were internally consistent it would provide strong support for the three assumptions discussed above. If these assumptions were validated, it would have important implications for how we view deformation partitioning in ductilely deformed rocks, and for the porphyroblast rotation/non-rotation issue.

\section{In-situ age determinations}

In-situ mineral-age determinations have recently been accomplished using isotopic ratios obtained by several methods, including: (1) electron microprobe analysis of staurolite (Lanzirotti and Hanson 1997) and monazite (Williams et al. 1999); (2) secondary ion mass spectrometry (SIMS) on monazite inclusions in garnet (Zhu et al. 1997); and (3) laser ablation techniques on igneous potassium feldspar using an inductively coupled plasma mass spectrometer (ICP-MS; e.g., Christensen et al. 1995). These methods represent exciting new advances for structural and metamorphic geologists because they allow age determinations for minerals that are in specific microstructural contexts, and may also allow the " $t$ " in $P-T-D-t$ paths to be quantified at different points along these paths. Two potential limitations with these methods are: (1) low concentrations of relevant isotopes in the minerals of interest; and (2) the deliterious effects that submicroscopic inclusions can have on the results. However, as technology improves, these potentially powerful methods may add considerably to our understanding of porphyroblast growth rates, durations of cleavage-forming events, and the relative timing relationships among deformation, metamorphism, and magmatism in a wide range of crustal settings.

\section{CONCLUDING REMARKS}

One of the major problems confronting structural and metamorphic geologists is that we have limited access to information about the deformation and metamorphic history that a rock has experienced. To access the early history of a deformed metamorphic rock, we must find appropriate "windows" into the past. For paleontologists this window is the fossil record. For structural and metamorphic geologists a useful window is the history of deformation and metamorphic-mineral development preserved in and around porphyroblasts that grew sequentially or episodically during orogenesis. This paper has reviewed some current applications of porphyroblast microstructures, all of which have the potential to reveal important new information about the inter-relationships among deformation and metamorphism (and in some instances magmatism).

A pressing issue that is linked inextricably to most applications of these microstructures is porphyroblast kinematics: what factors control their rotational behavior during ductile deformation? More work is required before we can claim to have a sound understanding of this issue, but a time may come in the not-too-distant future when these obstacles have been resolved, and traditional and newly developed techniques of microstruc- tural analysis are combined with emerging chemical and microprobe techniques. This combination will allow us to achieve an unparalleled understanding of the processes and timing relationships between deformation and metamorphism.

Examples of new understandings that might emerge include the following. (1) With more-precise, in-situ age determinations of porphyroblasts, it may be possible to determine the ages of specific deformation events in which individual porphyroblasts, or even portions of individual porphyroblasts, grew. Thus, it may be possible to quantify the length- and timescales of deformation/metamorphic cycles during orogenesis. (2) More-precise methods for determining isotopic zonations in porphyroblasts may provide new insights into strain rates, and their spatial and temporal variations. Combining these methods with precise, in-situ chronology may also add new insights into rates of metamorphic mineral growth relative to rates of foliation development. (3) Detailed determinations of FIA orientations preserved in porphyroblasts, combined with precise, in-situ chronology for different porphyroblast growth zones, may help to constrain relative tectonic plate motions during orogenesis. FIA orientation data may also improve our understand of folding mechanisms by providing constraints on how, and if, porphyroblasts rotate during folding. (4) More orientation data for both inclusion trails and FIAs preserved in porphyroblasts may help to answer the question of whether or not these orientations reflect fundamental dynamic processes that occur during orogenesis.

Owing to the controversial nature of porphyroblast microstructures, it seems important that each new paper make an attempt to clarify the assumptions on which interpretations are based, and illustrate ambiguities or inherent difficulties encountered. Papers that attempt to clarify these issues are likely to be more widely accepted by readers and, in the long run, will provide a better foundation on which to build this rapidly growing subdiscipline of structural and metamorphic geology.

\section{ACKNOWLEDGMENTS}

This work was supported by the Australian Research Council in the form of a Queen Elizabeth II Research Fellowship and Large Grant No. A39700451. Scott Paterson is thanked for comments on the manuscript while I was writing an early version at the University of Southern California. Later comments by Win Means and particularly Ron Vernon are also acknowledged. Reviews by Ken Hickey, Gary Solar, and Mike Williams led to important improvements to the manuscript.

\section{REFERENCES CITED}

Aerden, D.G.A.M. (1994) Kinematics of orogenic collapse in the Variscan Pyrenees deduced from microstructures in porphyroblastic rocks from the Lys-Caillaouas massif. Tectonophysics, 238, 139-160.

(1995) Porphyroblast non-rotation during crustal extension in the Variscan Lys-Caillaouas Massif, Pyrenees. Journal of Structural Geology, 17, 709-725.

Barker, A.J. (1994) Interpretation of porphyroblast inclusion trails: limitations imposed by growth kinetics and strain rates. Journal of Metamorphic Geology, 12, 681-694.

Bell, T.H. (1981) Foliation development: the contribution, geometry and significance of progressive bulk inhomogeneous shortening. Tectonophysics, 75, 273 296.

(1985) Deformation partitioning and porphyroblast rotation in metamorphic rocks: a radical reinterpretation. Journal of Metamorphic Geology, 3, 109-118.

Bell, T.H. and Forde, A. (1995) On the significance of foliation patterns preserved around folds by mineral overgrowths. Tectonophysics, 246, 171-181.

Bell, T.H. and Hayward, N. (1991) Episodic metamorphic reactions during orogenesis: the control of deformation partitioning on reaction sites and reaction duration. Journal of Metamorphic Geology, 9, 619-640. 
Bell, T.H. and Hickey, K.A. (1997) Distribution of pre-folding linear indicators of movement direction around the Spring Hill Synform, Vermont: significance for mechanism of folding in this portion of the Appalachians. Tectonophysics, 274 274-294.

- (1999) Complex microstructures preserved in rocks with a simple matrix: significance for deformation and metamorphic processes. Journal of Metamorphic Geology, 17, 521-536.

Bell, T.H. and Johnson, S.E. (1989) Porphyroblast inclusion trails: the key to orogenesis. Journal of Metamorphic Geology, 7, 279-310.

-1992) Shear sense: a new approach that resolves conflicts between criteria in metamorphic rocks. Journal of Metamorphic Geology, 10, 99-124.

Bell, T.H. and Rubenach, M.J. (1983) Sequential porphyroblast growth and crenulation cleavege developement during progressive deformation. Tectonophysics, 92, 171-194.

Bell, T.H., Fleming, P.D., and Rubenach, M.J. (1986) Porphyroblast nucleation, growth and dissolution in regional metamorphic rocks as a function of deformation partitioning during foliation development. Journal of Metamorphic Geology, 4, p. 37-67.

Bell, T.H., Forde, A., and Hayward, N. (1992) Can smoothly curving spiral-shaped inclusion trails form without rotation of the porphyroblast? Geology, 20, 5962.

Bell, T.H., Johnson, S.E., Davis, B., Forde, A., Hayward, N., and Wilkins, C. (1992) Porphyroblast inclusion-trail orientation data: eppure non son girate! Journal of Metamorphic Geology, 10, 295-307.

Bell, T.H., Forde, A., and Wang, J. (1995) A new indicator of movement direction during orogenesis: measurement technique and application to the Alps.Terra Nova, 7, 500-508.

Bell, T.H., Hickey, K.A., and Wang, J. (1997) Spiral and staircase inclusion trail axes within garnet and staurolite porphyroblasts from the schists of the Bolton Syncline, Connecticut: timing of porphyroblast growth and the effects of fold development. Journal of Metamorphic Geology, 15, 467-478.

Bell, T.H., Hickey, K.A., and Upton, G.J.G. (1998) Distinguishing and correlating multiple phases of metamorphism across a multiply deformed region using the axes of spiral, staircase and sigmoidal inclusion trails in garnet. Journal of Metamorphic Geology, 16, 767-794.

Beutner, E.C., Fisher, D.M., and Kirkpatrick, J.L. (1988) Kinematics of deformation at a thrust fault ramp (?) from syntectonic fibers in pressure shadows. Geological Society of America Special Paper, 222, 77-88.

Bjørnerud, M.G. and Zhang, H. (1994) Rotation of porphyroblasts in non-coaxia deformation: insights from computer simulations. Journal of Metamorphic Geology, 12, 135-139.

Busa, M.D. and Gray, N.H. (1992) Rotated staurolite porphyroblasts in the Littleton Schist at Bolton, Connecticut, USA. Journal of Metamorphic Geology, 10, 627 636.

Christensen, J.N., Rosenfeld, J.L., and DePaolo, D.J. (1989) Rates of tectonometamorphic processes from rubidium and strontium isotopes in Garnet. Science, 244, 1465-1469.

Christensen, J.N., Selverstone, J., Rosenfeld, J.L., and DePaolo, D.J. (1994) Correlation by $\mathrm{Rb}-\mathrm{Sr}$ geochronology of garnet growth histories from different structural levels within the Tauern Window, Eastern Alps. Contributions to Mineralogy and Petrology, 118, 1-12.

Christensen, J.N., Halliday, A.N., Lee, D-C., and Hall, C.M. (1995) In situ Sr isotopic analysis by laser ablation. Earth and Planetary Science Letters, 136, 79-85.

Davis, B.K. (1993) Mechanism of emplacement of the Cannibal Creek Granite with special reference to timing and deformation history of the aureole. Tectonophysics, 224, 337-362.

England, P.C. (1987) Diffuse continental deformation; length scales, rates and metamorphic evolution. Philosophical Transactions of the Royal Society of London, Series A, 321, 3-22.

Etheridge, M.A., Cox, S.F., Wall, V.F., and Vernon, R.H. (1984) High fluid pressures during regional metamorphism and deformation - implications for mass transport and deformation mechanisms. Journal of Geophysical Research, 89, $4344-4358$.

Etheridge, M.A., Wall, V.F., and Vernon, R.H. (1983) The role of fluid phase during regional metamorphism and deformation. Journal of Metamorphic Geology, 1 , 205-226.

Flinn, D. (1994) Essay review: kinematic analysis — pure nonsense or simple nonsense? Geological Journal, 29, 281-284

Forde, A. and Bell, T.H. (1993) The rotation of garnet porphyroblasts around a single fold, Lukmanier Pass, Central Alps: Discussion and reply. Journal Structura Geology, 15, 1365-1372.

Fyson, W.K. (1980) Fold fabrics and emplacement of an Archean granitoid pluton, Cleft Lake, Northwest Territories. Canadian Journal of Earth Sciences, 17, 325332.

Goldstein, A., Knight, J., and Kimball, K. (1998) Deformed graptolites, finite strain and volume loss during cleavage formation in rocks of the taconic slate belt, New York and Vermont, U.S.A. Journal of Structural Geology, 20, 1769-1782.

Gray, D.R. (1979) Geometry of crenulation-folds and their relationship to crenulation cleavage. Journal of Structural Geology, 1, 187-205.

Gray, N.H. and Busa, M.D. (1994) The three-dimensional geometry of simulated porphyroblast inclusion trails: inert marker, viscous flow models. Journal of Metamorphic Geology, 12, 575-587.

Hayward, N. (1990) Determination of early fold-axis orientations in multiply deformed rocks using porphyroblast inclusion trails. Tectonophysics, 179, 353369.

(1992) Microstructural analysis of the classic spiral garnet porphyroblasts of southeast Vermont: evidence for non-rotation. Journal of Metamorphic Geology, 10, 567-587.

Helmstaedt, H. and Dixon, J.M. (1980) Superposed crenulation cleavages resulting from progressive deformation. Tectonophysics, 66, 115-126.

Hickey, K.A and Bell, T.H. (1999) Behaviour of rigid objects during deformation and metamorphism: a test using schists from the Bolton syncline, Connecticut, USA. Journal of Metamorphic Geology, 17, 21-228.

Hobbs, B.E., Means, W.D. and Williams, P.F. (1976) An outline of structural geology, 571 p. Wiley, New York.

Jamieson, R.A. and Vernon, R.H. (1987) Timing of porphyroblast growth in the Fleur de Lys Supergroup, Newfoundland. Journal of Metamorphic Geology, 5 273-288.

Johnson, S.E. (1990a) Lack of porphyroblast rotation in the Otago schists, New Zealand: implications for crenulation cleavage development, folding and deformation partitioning. Journal of Metamorphic Geology, 8, 13-30.

(1990b) Deformation history of the Otago schists, New Zealand, from progressively developed porphyroblast-matrix microstructures: uplift-collapse orogenesis and its implications. Journal of Structural Geology, 12, 727-746.

(1992) Sequential porphyroblast growth during progressive deformation and low-P high-T (LPHT) metamorphism, Cooma Complex, Australia: The use of microstructural analysis in better understanding deformation and metamorphic histories. Tectonophysics, 214, 311-339.

(1993a) Testing models for the development of spiral-shaped inclusion trails in garnet porphyroblasts: to rotate or not to rotate, that is the question. Journal of Metamorphic Geology, 11, 635-659.

(1993b) Unraveling the spirals: A serial thin section study and three-dimensional computer-aided reconstruction of spiral-shaped inclusion trails in garnet porphyroblasts. Journal of Metamorphic Geology, 11, 621-634.

(1999a) Back-rotation during crenulation cleavage development: implication for structural facing and cleavage-forming processes. Journal of Structural Geology, 21, 139-145.

(1999b) Near-orthogonal foliation development in orogens: meaningless complexity, or reflection of fundamental dynamic processes? Journal of Structura Geology, 21, 1183-1187.

Johnson, S.E. and Bell, T.H. (1996) How useful are "millipede" and other similar porphyroblast microstructures for determining synmetamorphic deformation histories? Journal of Metamorphic Geology, 14, 15-28.

Johnson, S.E. and Moore, R.R. (1996) De-bugging the "millipede" porphyroblas microstructure: a serial thin-section study and 3-D computer animation. Journal of Metamorphic Geology, 14, 3-14.

Johnson, S.E. and Vernon, R.H. (1995a) Stepping stones and pitfalls in the determination of an anticlockwise P-T-t-deformation path: the low-P, high-T Cooma Complex, Australia. Journal of Metamorphic Geology, 13, 165-183.

(1995b) Inferring the timing of porphyroblast growth in the absence of continuity between inclusion trails and matrix foliations: can it be reliably done? Journal of Structural Geology, 17, 1203-1206.

Johnson, S.E. and Williams, M.L. (1998) Determining finite longitudinal strains from oppositely concave microfolds in and around porphyroblasts: A new quantitative method. Journal of Structural Geology, 11, 1521-1530.

Jones, K.A. (1994) Progressive metamorphism in a crustal-scale shear zone: an example from the Leon region, north-west Brittany, France. Journal of Metamorphic Geology, 12, 69-88.

Karabinos, P. (1984) Polymetamorphic garnet zoning from southeastern Vermont. American Journal of Science, 284, 1008-1025.

Karlstrom, K.E. and Williams, M.L. (1995) The case for simultaneous deformation, metamorphism and plutonism: an example from Proterozoic rocks in central Arizona. Journal of Structural Geology, 17, 59-81.

Kennan, P. (1971) Porphyroblast rotation and the kinematic analysis of a small fold. Geological Magazine, 108, 221-228.

Ketcham, R.A and Carlson, W.D. (2000) Acquisition, optimization and interpretation of X-ray computed tomographic imagery: applications to the geosciences. In 3-D Reconstruction and Modelling of Geological Materials (eds. Marschallinger, R. and Johnson, S.E.). Computers and Geosciences, in press.

Kraus, J. and Williams, P.F. (1998) Relationships between foliation development, porphyroblast growth and large-scale folding in a metaturbidite suite, Snow Lake, Canada. Journal of Structural Geology, 20, 61-76.

Lang, H.M. and Dunn, G.R. (1990) Sequential porphyroblast growth during deformation in a low-pressure metamorphic terrane, Orrs Island - Harpswell Neck, Maine. Journal of Metamorphic Geology, 8, 199-216.

Lanzirotti, A., and Hanson, G.N. (1997) An assessment of the utility of staurolite in $\mathrm{U}-\mathrm{Pb}$ dating of metamorphism. Contributions to Mineralogy and Petrology, 129, $352-365$.

Masuda, T. and Mochizuki, S. (1989) Development of snowball structure: numerical simulations of inclusion trails during synkinematic porphyroblast growth in 
metamorphic rocks. Tectonophysics, 170, 141-150.

Means, W.D. (1999) Reversed structures and bounce structures: Are they recognizable? Are they real? Journal of Structural Geology, in press.

Mitra, G. and Yonkee, W.A. (1985) Relationship of spaced cleavage to folds and thrusts in the Idaho-Utah-Wyoming thrust belt. Journal of Structural Geology, 7, 361-373.

Morgan, S.S., Law, R.D., and Nyman, M.W. (1998) Laccolith-like emplacement model for the Papoose Flat pluton based on porphyroblast-matrix analysis. Geological Society of America Bulletin, 110, 96-110.

Olesen, N.O. (1982) Heterogeneous strain of a phyllite as revealed by porphyroblastmatrix relationships. Journal of Structural Geology, 4, 481-490.

Passchier, C.W. and Speck, P.J.H.R. (1994) The kinematic interpretation of obliquely transected porphyroblasts: an example from the Trois Seigneurs Massif, France. Journal Structural Geology, 16, p. 971-984.

Passchier, C.W., Trouw, R.A.J., Zwart, H.J. and Vissers, R.L.M. (1992) Porphyroblast rotation: eppur si muove? Journal of Metamorphic Geology, 10, 283-294

Paterson, S.R. and Tobisch, O.T. (1992) Rates of processes in magmatic arcs: implications for the timing and nature of pluton emplacement and wall rock deformation. Journal of Structural Geology, 14, 291-300.

Paterson, S.R., Vernon, R.H. and Fowler, T.K. (1991) Aureole tectonics. In Mineralogical Society of America Reviews in Mineralogy, 26, 673-722.

Pfiffner, O. A. and Ramsay, J.G. (1982) Constraints on geological strain rates; arguments from finite strain states of naturally deformed rocks. Journal of Geophysical Research, B 87, 311-321.

Phillips, E.R. and Key, R.M. (1992) Porphyroblast-fabric relationships: an example from the Appin Group in the Glen Roy area. Scottish Journal of Geology, $28,89-101$.

Pouget, P. (1991) Hercynian tectonometamorphic evolution of the Bosost dome (French-Spanish central Pyrenees). Journal of the Geological Society, London, 148, 299-314.

Powell, C. McA. and Vernon, R.H. (1979) Growth and rotation history of garne porphyroblasts with inclusion spirals in a Karakoram schist. Tectonophysics, $54,25-43$.

Powell, D. \& MacQueen, J.A. (1976) Relationships between garnet shape, rotational inclusion fabrics and strain in some Moine metamorphic rocks of Skye, Scotland. Tectonophysics, 35, 391-402.

Rajlich, P. (1993) Riedel shear: a mechanism for crenulation cleavage. Earth-Science Reviews, 34, 167-195.

Ramsay, J.G. (1962) The geometry and mechanics of formation of 'similar' type folds. Journal of Geology, 70, 309-327.

Ramsay, J.G. and Huber, M.I. (1983) The Techniques of Modern Structural Geology, Volume 1: Strain Analysis. Academic Press, London.

Reinhardt, J. and Rubenach, M.J. (1989) Temperature-time relationships across metamorphic zones: evidence from porphyroblast-matrix relationships in progressively deformed metapelites. Tectonophysics, 158, 141-161.

Rice, A.H.N. (1984) Metamorphic and structural diachroneity in the Finnmarkian nappes of north Norway. Journal of Metamorphic Geology, 2, 219-236.

Rosenfeld, J.L. (1968) Garnet rotations due to major Paleozoic deformations in Southeast Vermont. In E-an Zen, Ed., Studies of Appalachian Geology p. 185202. Wiley, New York.

(1970) Rotated garnets in metamorphic rocks. Geological Society of America Special Paper 129, 105p

Rubenach, M.J. (1992) Proterozoic low-pressure/high-temperature metamorphism and an anticlockwise P-T-t path for the Hazeldene area, Mount Isa Inlier, Queensland, Australia. Journal of Metamorphic Geology, 10, 333-346.

Sanderson, D.J. and Meneilly, A.W. (1981) Analysis of three-dimensional strain modified uniform distributions: andalusite fabrics from a granite aureole. Journal of Structural Geology, 3, 109-116.

Schoneveld, C. (1977) A study of some typical inclusion pattems in strongly paracrystalline-rotated garnets. Tectonophysics, 39, 453-471.

Schoneveld, C. (1979) The Geometry and the Significance of Inclusion Patterns in Syntectonic Porphyroblasts, $125 \mathrm{p}$. Ph.D. dissertation, University of Leiden.

Solar, G.S. and Brown, M. (1999) The classic high-T-low-P metamorphism of westcentral Maine, USA: is it post-tectonic or syn-tectonic? Evidence from porphyroblast-matrix relations. Canadian Mineralogist, in press.

Soula, J.-C. (1982) Characteristics and mode of emplacement of gneiss domes and plutonic domes in central-eastern Pyrenees. Journal of Structural Geology, 4 313-342.

Spiess, R. and Bell, T.H. (1996) Microstructural controls on sites of metamorphic reaction: a case study of the inter-relationship between deformation and metamorphism. European Journal of Mineralogy, 8, 165-186.

Spry, A. (1963) The origin and Significance of snowball structure in garnet. Journal of Petrology, 4, 211-222.

Steinhardt, C.K. (1989) Lack of porphyroblast rotation in non- coaxially deformed schists from Petrel Cove, South Australia, and its implications. Tectonophysics, $158,127-140$

Stewart, L.K. (1997) Crenulation cleavage development by partitioning of deformation into zones of progressive shearing (combined shearing, shortening and volume loss) and progressive shortening (no volume loss): quantification of solution shortening and intermicrolithon movement. Tectonophysics, 281, 125140.

Turner, F.J. (1948) Mineralogical and structural evolution of the metamorphic rocks Memoir of the Geological Society of America, 30.

Vance, D. and O'Nions, R.K. (1992) Prograde and retrograde thermal histories from the central Swiss Alps. Earth and Planetary Science Letters, 114, 113-129.

Vernon, R.H. (1976) Metamorphic Processes (Reactions and Microstructure Development). Allen and Unwin, London.

(1978) Porphyroblast-matrix microstructural relationships in deformed metamorphic rocks. Geologische Rundschau, 68, 288-305.

(1987) Growth and concentration of fibrous sillimanite related to heterogeneous deformation in K-feldspar-sillimanite metapelites. Journal of Metamorphic Geology, 5, 51-68.

(1988a) Evidence of syndeformational contact metamorphism from porphyroblast-matrix microstructural relationships. Tectonophysics, 158, 113126.

(1988b) Sequential growth of cordierite and andalusite porphyroblasts, Cooma Complex, Australia: microstructural evidence of a prograde reaction. Journal of Metamorphic Geology, 6, 255-269.

(1989) Porphyroblast-matrix microstructural relationships: recent approaches and problems. In J.S. Daly, R.A. Cliff, and B.W. Yardley, Ed., Evolution of Metamorphic Belts, p. 83-102. Geological Society Special Publication 43.

Vernon, R.H., Collins, W.J. and Paterson, S.R. (1992) Pre-foliation metamorphism in low-pressure/high-temperature terrains. Tectonophysics, 219, 241-256.

Vernon, R.H., Paterson, S.R., and Foster, D. (1993) Growth and deformation of porphyroblasts in the Foothills terrane, central Sierra Nevada, California: negotiating a microstructural minefield. Journal of Metamorphic Geology, 11, 203222.

Visser, P. and Mancktelow, N.S. (1992) The rotation of garnet porphyroblasts around a single fold, Lukmanier Pass, Central Alps. Journal Structural Geology, 14 $1193-1202$.

Vissers, R.L.M. (1992) Variscan extension in the Pyrenees. Tectonics, 11, 13691384

Wilkins, C. (1993) A post-deformational, post-peak metamorphic timing for mineralization at the Archean Big Bell gold deposit, Western Australia. Ore Geology Reviews, 7, 439-483.

Williams, M.L. (1994) Sigmoidal inclusion trails, punctuated fabric development, and interactions between metamorphism and deformation. Journal of Metamorphic Geology, 12, 1-21.

Williams, M.L., Jercinovic, M.J. and Terry, M.P. (1999) Age mapping and dating of monazite on the electron microprobe: deconvoluting multistage tectonic histories. Geology, 367-378.

Williams, P.F. and Schoneveld, C. (1981) Garnet rotation and the development of axial plane crenulation cleavage. Tectonophysics, 78, 307-334

Williams, P.F. and Jiang, D. (1999) Rotating garnets. Journal of Metamorphic Geology, 17 , in press.

Wilson, M.R. (1971) On syntectonic porphyroblast growth. Tectonophysics, 11, 239260.

Zhu, X.K., O’Nions, R.K., Belshaw, N.S., and Gibb, A.J. (1997) Lewisian crusta history from in situ SIMS mineral chronometry and related metamorphic textures. Chemical Geology, 136, 205-218.

Zwart, H.J. (1960) The chronological succession of folding and metamorphism in the central Pyrenees. Geologische Rundschau, 50, 203-218.

(1962) On the determination of polymetamorphic mineral associations and its application to the Bosost area (Central Pyrenees). Geologische Rundschau, 52, $38-65$.

(1979) The geology of the central pyrenees. Leidse Geologische Mededelingen, $50,1-74$.

Zwart, H.J. and Oele, J.A. (1966) Rotated magnetite crystals from the Rocroi Massif (Ardennes). Geologie en Mijnbouw, 45, 70-74.

MANUSCRIPT RECEIVED OCTOBER 19, 1998

MANUSCRIPT ACCEPTED JULY 14, 1999

PAPER HANDLED BY PHILIP PICCOLI 